\title{
CHRONICLE OF EVENTS AND INCIDENTS RELATING TO ASIA WITH RELEVANCE TO INTERNATIONAL LAW
}

July 1997 - June 1999

\author{
Ko Swan Sik
}

\section{TABLE OF HEADINGS}

Air traffic and transport

Arms sales and supplies

Asia-Pacific Economic Co-operation forum (APEC)

Association of South East Asian

Nations (ASEAN)

Borders, border disputes and border incidents

Boycott

Civil war

Diplomatic and consular immunity and inviolability

Diplomatic and consular relations

Disarmament and arms control

Divided states: Korea

Embargo

Environmental pollution and protection

Group of 15 Developing Nations

High Seas

Hong Kong

Human rights

Immigration

Insurgents
Inter-state relations: general aspects

International Criminal Law

International economic relations and trade

(Non-)Intervention

Japan's military role

Joint development and joint ventures

Judicial assistance

Jurisdiction

Korean War

Law of armed conflict

Lease of territory

Mercenaries

Middle East issues

Migrant workers

Military alliances

Military co-operation

Missile technology

Monetary and financial matters

Nuclear energy matters

Oil and gas

Organization of the Islamic

Conference (OIC)

Recognition

Refugees

\footnotetext{
" General Editor.For the considerations underlying the Chronicle, see the "Editorial Introduction"
} in 1 AsianYIL (1991) 265.

Asian Yearbook of International Law, Volume 8 (B.S. Chimni et al., eds.)

(c) 2003 Koninklijke Brill NV. Printed in The Netherlands, pp. 251-315. 
Regional security

Rivers

Sanctions

Self-defence

Self-determination

Space activities

Specific territories within a state: East

Timor

Specific territories within a state:

Kashmir
State responsibility

Territorial claims and disputes

Territorial sovereignty

Terrorism

United Nations

Weapons

World War II

\section{AIR TRAFFIC AND TRANSPORT}

\section{Opening of North Korean airspace}

North and South Korea concluded an air traffic agreement in Bangkok on 8 October 1997, allowing foreign commercial flights to cross North Korean airspace. This had not occurred since 1945, except for Russian and Chinese airlines.(IHT 09-1097;JP 09-10-97)

\section{Japan-US civil aviation agreement}

An interim agreement on current disputes (see 6 AsYIL 332; 7 AsYIL 392) was reached and signed on 30 January 1998. The number of US flights with access to Japan would be considerably increased, in exchange for All Nippon Airways being added to Japan Airlines as entitled to unlimited access to the US. The remaining dispute was said to be about Japanese resistance to code-sharing by US carriers for flights from Japan on to third destinations.(IHT 16-12-97;21-01, 31-01/01-02-98)

\section{Iranian scheduled flights to Saudi Arabia resumed}

Iran resumed scheduled flights to Saudi Arabia in September 1997 after an 18year interruption, since the 1979 Islamic Revolution in Iran. An agreement between the two countries stipulated that Saudi Arabia would also start weekly flights to Tehran.(JP 22-09-97)

\section{Open-sky agreements with US}

Among the Asian countries only Brunei, Malaysia, and Singapore had so-called open-sky agreements with the US in late 1997, including the "seventh freedom", which allows a carrier to handle traffic between two countries neither of which is its home country. South Korea and the Philippines were expected to follow soon.(JP 13-11-97) 


\section{Thai-Australian aviation agreement to be scrapped}

Thailand was likely to scrap an air transport agreement with Australia after a two-year deadlock in negotiations. Australia wanted more so-called fifth freedom rights. Thailand blocked these efforts since reciprocal rights with Australia would bring an extension only of Thai flights to New Zealand, while Australian carriers would enjoy a far broader network.(JP 18-11-97)

\section{ARMS SALES AND SUPPLIES}

\section{Arms sales to Indonesia}

Indonesia announced it would buy military aircraft from Russia, while canceling an order for US planes because of Congressional attacks on its human rights record. The Indonesian and Russian governments were still finalizing details of the payment conditions, but at least part of it would be by way of a counter-trade arrangement.(IHT 06-08-97;JP 25-08, 27-08-97)

The UK government in late September 1997 announced its refusal of export licences for a shipment of armoured personnel carriers and sniper rifles to Indonesia, resulting from new criteria for arms sales.(JP 07-10-97)

The US Congress included a clause in a foreign aid spending bill on 13 November 1997 urging the government not to supply to Indonesia arms that could be used in East Timor.(JP 16-11-97)

\section{Weapons trade}

It was reported by the US Congressional Research Service in 1998 that the US had in the past seven years been the world's biggest arms supplier, with sales of $\$ 15.2$ billion worth of weapons in 1997 , a 44 per cent share of the arms market. Developing countries were the largest buyers of US weapons. A presidential order of 1995 laying down US policy on weapons sales said that the sales were "a legitimate instrument of US foreign policy". Asia is the second-largest regional market after the Middle East.(IHT 05-08-98)

\section{Russian MiG-29s for Bangladesh}

The two countries signed a contract on 28 June 1999 concerning the purchase of eight MiG-29 combat aircraft by Bangladesh.(IHT 30-06-99)

\section{ASIA-PACIFIC ECONOMIC CO-OPERATION FORUM (APEC)}

\section{Annual meetings and membership}

The APEC annual meetings were held in Vancouver and Kuala Lumpur in November 1997 and November 1998. Russia, Vietnam and Peru were admitted as Members at the 1998 conference.(IHT 13-11-98) 


\section{Annual summit 1998}

The meeting was dominated by the different approaches in confronting the financial crisis in Asia.

Malaysia raised the issue of short-term capital flows and hedge funds, which it blamed for the Asian financial crisis, and sought to obtain APEC backing for their regulation. On the other hand, there were those who remained firmly committed to market-oriented policies. The result as contained in the Joint Declaration appeared to be an uneasy compromise: a task force was to be set up to examine the questions.(IHT 09-11-98)

The major food exporting countries (US, Australia, Canada, and New Zealand) pressed for implementation of a "fast-track" trade liberalization plan, including tariff cuts in nine sectors valued at more than $\$ 1.5$ trillion a year. The plan was agreed at the 1997 summit conference in an Early Voluntary Sectoral Liberalization accord. In view of the Asian economic crisis Japan and other Asian countries such as China, Indonesia, Thailand and Malaysia were not in favour and stressed the voluntary nature of the plan. On the other hand, the US had recently posted record trade deficits because of the significant depreciation of Asian currencies against the dollar, which could trigger a protectionist backlash.(IHT 13-11-98) The issue was finally submitted to the WTO.

The issue of a blueprint for global financial change was amended into an expanded version of the Group of 22 which links finance ministers and central bankers from developed and emerging states.(IHT 20-11-98)

\section{Speed of trade liberalization}

In 1999 there was a growing rift among the APEC members on the issue of how fast their economies should be liberalized. The group in support of faster liberalization, including Australia, New Zealand and Singapore, was opposed by Japan and other East Asian countries reluctant both to open their economies too fast and to open sensitive sectors in view of their recent recovery from economic crisis. Also, the US showed an increasingly protectionist attitude.

The trade ministers of the group gathered for talks on this and other issues in Auckland in late June in preparation for the 1999 annual summit meeting in New Zealand and to forge a unified position for the WTO ministerial meeting in Seattle in November 1999.(IHT 28-06-99)

\section{ASSOCIATION OF SOUTH EAST ASIAN NATIONS}

\section{The admission of Cambodia}

(See also: Civil War: Cambodia)

In a move to increase international pressure for a negotiated end to the political conflict in Cambodia and because of "the unfortunate circumstances that have resulted from the use of force", the ASEAN foreign ministers announced at a special meeting 
in Kuala Lumpur on 10 July 1997 that they would indefinitely delay Cambodia's admission to the organization, which had been scheduled for that month.

The position of the organization was regarded to have weakened when both the US and Australia on 14 July dropped demands that the ousted co-prime minister of Cambodia be reinstated, characterizing such demands as unrealistic.(IHT 11-07, 16-0797)

ASEAN set up a team of three foreign ministers to mediate in the struggle in Phnom Penh. They obtained the approval from the king, while the Chinese foreign minister said China opposed any excessive outside interference. As to ASEAN's decision to postpone Cambodia's admission the Indonesian foreign minister said, inter alia: "We did not pass judgment on who was wrong or right, but there were armed clashes, high tensions and instability and under these circumstances we thought it was a wise thing to postpone Cambodia's admission as a full member.'(IHT 18-0797) The mediation attempts were for all practical purposes rejected by the ruling prime minister, who urged ASEAN not to interfere with the internal affairs of Cambodia.

The resulting diplomatic isolation of Cambodia was favourable for US efforts to increase international pressure on the Cambodian government for it to make political concessions, such as calling on donors to use aid to Cambodia as leverage. Besides, it was reported that Vietnam, which, together with Malaysia, was seeking a reversal of the ASEAN decision to delay Cambodia's entry as a member, was told by the US of the importance of its continued support of the regional consensus for the bilateral Vietnam-US relationships, among which are the early approval of a trade agreement and easier access to US markets.(IHT 21-07-97) As to the similarities and differences between the respective US and ASEAN positions on Cambodia, the Indonesian foreign minister said that although there was a convergence "in general terms" between those positions there were also differences, including the US decision to suspend part of its aid by considering a complete halt to all but humanitarian assistance: "We don't believe in sanctions easily."(IHT 25-07097)

At the Kuala Lumpur meeting of foreign ministers in July 1997 it appeared that ASEAN would continue not to recognize formally the removal of the first prime minister while not insisting on his return to office as long as Cambodia maintained the coalition government set up after the UN-supervised elections in 1993.(IHT 24-0797)

On the other hand a "new [Cambodian] position" appeared to emerge as was expressed by a Cambodian welcoming of a mediating role for ASEAN(IHT 26/27-0797), although it was not clear what that role would in fact entail. It was also unclear either whether ASEAN still considered the ousted co-prime minister as legally still holding that position. As to the question whether ASEAN recognized the person who had in fact taken over the position as the first prime minister, a joint statement of the ASEAN foreign ministers said that the question did not arise "because ASEAN member states recognize states, not governments".

A difficult discussion developed within ASEAN on the question to what extent the admission of Cambodia should be postponed. On the one hand there were those who wanted to let Cambodia join by December so that ASEAN could achieve its 
aim of including all ten countries of the region. Other members emphasized another vital principle to be at stake, viz. the use of force in disrupting the coalition government and constitutional rule.(IHT 11-08-97)

The ASEAN summit of December 1998 "decided to admit" Cambodia as a member. The actual admission took place on 30 April 1999 by a joint ministerial declaration.(IHT 15-12-98 and 30-04/02-05-99;ASEAN Doc.Ser. 1998-1999)

\section{7 and 1998 Summit Meetings}

The Second Informal ASEAN Summit was held in Kuala Lumpur on 14-16 December 1997 and the Sixth ASEAN Summit 1998 in Hanoi on 15-16 December 1998.

\section{Admission of Myanmar and Laos}

The two countries were officially admitted to membership on 23 July 1997 at a meeting of foreign ministers in Kuala Lumpur.(IHT 24-07-97)

\section{Myanmar participation in ASEAN-EU meeting}

The Thai foreign ministry said on 30 October 1997 that the EU had agreed to Myanmar participation in an ASEAN-EU joint cooperation meeting in November 1997. However, Myanmar as well as another new ASEAN member, Laos, would attend only as observers.(JP 31-10-97) [The meeting was finally cancelled.]

\section{ASEAN plus Three}

(See also: Monetary and financial matters)

During his Southeast Asia tour in January 1997 the Japanese prime minister had called for regular meetings between Japan and ASEAN countries.(See 7 AsYIL 441) The latter extended the idea by inviting Japan, China, and South Korea to a "commemorative summit" meeting to be held in Malaysia in December 1997 to celebrate ASEAN's thirtieth anniversary.

The Informal Summit Meeting in December was followed by bilateral and collective meetings of the ASEAN heads of state with their counterparts from China, Japan and South Korea. After having developed close links with mostly Western and Western-inclined countries in the past, ASEAN would now have moved to meet with exclusively Asian non-member countries.(IHT 2/3-08 and 04-09-97) The meeting did not, however, reach agreement on regular pan-Asian meetings.(IHT 16-12 and 17-12-97)

The issue of non-interference in each other's internal affairs, and a peer surveillance mechanism

The Association decided in early December 1997 to monitor the domestic economies of its members and evaluate their potential economic and financial risks, in order to prevent future financial crises. The system of peer surveillance implies a modification of ASEAN's policy of strict non-intervention in domestic affairs.(IHT 02-12-97) The system would join a wider system of East Asian surveillance by a monitoring body linked to the Tokyo office of the IMF. There would be some 
coordination of macro-economic policies and there could be "peer pressure" exerted on governments judged to be failing to meet certain standards.(IHT 09-02-98) The matter was again on the agenda on a meeting of the finance ministers in Washington in early October 1998 where agreement was reached on the early warning procedures.(IHT 08-10-98)

Another new phenomenon emerged in the form of the raising of human rights issues in other member states. The Philippine president openly criticized the prison sentence given to the former Malaysian deputy prime minister in April 1999, contrary to the tradition of non-interference.(See: (Non-)Intervention)

On a different aspect the ASEAN Secretary General divulged that the member states had begun to inform one another on their respective internal policies and reforms, and to exchange views on these.(IHT 22-04-99)

\section{"Flexible engagement"}

The Thai foreign minister said on 13 July 1998 that ASEAN must drop its longstanding policy of non-interference or "constructive engagement" and replace it with "flexible engagement" where members talk openly and frankly about national economic and political issues adversely affecting the region.(IHT 14-07-98)

\section{Accelerated implementation of the ASEAN Free Trade Area (AFTA)}

At its summit conference in December 1998 at Hanoi ASEAN agreed to speed up the implementation of AFTA. Under the new terms Brunei, Indonesia, Malaysia, the Philippines, Singapore, and Thailand would target, admittedly "with some flexibility", full implementation of the tariff-free zone by 2002 , i.e. a year earlier than in the original scheme. The more recent entrants, Vietnam, Laos, and Myanmar, also agreed to act more expeditiously, but with a more extended timetable.(IHT 17-12-98)

\section{ASEAN Inter-Parliamentary Organization (AIPO) Eighteenth session}

The AIPO held its Eighteenth Session from 1-5 September 1997 in Den Pasar, Bali. It issued a joint declaration and 42 resolutions, generally endorsing the agreements reached between the ASEAN members on cooperation. As a rule AIPO deals with the same items currently being discussed at the inter-governmental level in ASEAN. Although human rights was not the subject of a separate resolution, reference was made to the topic in the resolution on the WTO. AIPO rejected the efforts made to link agreement on international trade and investment to social issues such as labour standards, human rights, and democratization.

At the Eighteenth session Laos was accepted as the seventh member of AIPO, while Myanmar was made "special observer". The organization thus comprised the following members: Indonesia, Malaysia, the Philippines, Singapore, Thailand, Vietnam, and Laos. (Kompas 06-09-97;JP 01-09-97) 


\section{BORDERS, BORDER DISPUTES, AND BORDER INCIDENTS}

See also: Inter-state relations: Cambodia-Thailand; Oil and Gas: Division and sharing of Caspian oil

\section{Malaysian-Thai border wall}

Malaysia had built a 21-kilometre border wall along the Malaysia-Thai border, in its effort to prevent illegal immigrants from entering the country. The wall would also serve to reduce the smuggling of firearms, illegal drugs, and livestock. There was, however, still more than 250 miles of unwalled border.(IHT 22-09-97)

\section{Sino-Russian border pact}

China and Russia signed a declaration on 10 November 1997 on the final demarcation of their 4,300-kilometre border, during a visit by the Russian president to China. The border agreement laid out the eastern frontier, from Mongolia to the Tumen River near the Sea of Japan, and includes territory that was disputed as recently as 1969 . The agreement covers the joint use of islands and surrounding waters on the border, but it was not clear whether two disputed islands on the Amur River were included. The western border, only 50 kilometres long, was still under negotiation.(IHT 28-10, 09-11 and 11-11-97;JP 11-11-97)

\section{India-Pakistan maritime boundary dispute}

For the past 30 years there had been a maritime boundary dispute between India and Pakistan, blocking the exploration of oil and gas. The border in question is between the western Indian state of Gujarat and Sind Province of Pakistan. The line follows a shifting tidal channel known as Sir Creek, and the dispute led to armed clashes in 1965. Failure to determine this border at the mouth of Sir Creek had blocked agreement on the maritime boundary in the Arabian Sea, preventing the exploration of offshore deposits of oil and gas. Fishermen were also routinely mutually arrested in the disputed zone.

On 9 November 1998 Pakistan proposed international arbitration to resolve the dispute, a proposal rejected by India.(IHT 10-11-98)

\section{BOYCOTT}

\section{International conference in Myanmar boycotted by Western countries}

The Fourth International Heroin Conference was held in February 1999 in Yangon under the auspices of Interpol. The conference was boycotted by Western states such as the US, Britain, France, Germany, Denmark, The Netherlands, and Belgium, which saw their attendance as endorsement of the current Myanmar government and wished to avoid this.(IHT 24-02-99) 


\section{CIVIL WAR}

\section{Papua New Guinea}

Talks aimed at ending the secessionist war in Bougainville Island started in early July 1997 in New Zealand.(IHT 02-07-97)

\section{Cambodia}

(See also: Association of South East Asian Nations)

The Second Prime Minister (HUN SEN) seized power and declared victory in his confrontation against the First Prime Minister (NORODOM RANARIDDH), claiming full power. At the same time he announced he would remain second prime minister, apparently hoping to retain the structure of government fostered by the UN in 1993, and vowed to hold elections in May 1998 as scheduled.(IHT 07-07-97) He accused the first prime minister of being a "traitor" who should be put on trial, and of having recruited Khmer Rouge members to enter Phnom Penh. Meanwhile, the first prime minister, who was abroad at the time of the seizure of power, called on the international community not to recognize the government controlled by the second prime minister.(IHT 09-07-97)

The US condemned the use of force and after some hesitation announced the suspension of aid programs,(IHT 10-07-97 and 12/13-07-97) but after a few days there were signs of emerging international acceptance. Japan continued its aid although others, such as Australia, followed the example of the US. The titular leader and king of Cambodia also seemed to have granted support to the controlling prime minister, calling him "victorious" and saying that he himself "cannot become 'a judge' as to what is a 'coup' or a 'non-coup"'.(IHT 14-07,15-07 and 28-07-97)

Faced with military defeat and limited international support the deposed first prime minister conceded on 18 July that he would not be restored to power.(IHT 19/20-07-97) Early in August the king finally officially endorsed the replacement.(IHT 08-08-97)

In view of the prevailing situation of uncertainty, the UN decided to leave the Cambodian seat vacant at the 1997 General Assembly session. The leading prime minister of Cambodia thereupon threatened to suspend cooperation with the UN.(IHT 25-09-97)

On 27 February 1998 a cease-fire was declared by the two main competing forces in response to a peace process quietly mediated by Japan in the previous weeks.

Under the plan, there would be a military trial of the deposed co-prime minister in absentia, after which he would be pardoned by the King and return to Cambodia under a safety guarantee of the government. He would promise to cut ties with the Khmer Rouge and be allowed to campaign for the elections [due to be held on 26 July 1998].(IHT 28-02/01-03-98)

On 18 March 1998 the deposed co-prime minister was found guilty of conspiring with Khmer Rouge guerrillas to overthrow the government and was sentenced to 30 years in prison.(IHT 19-03-98) A royal amnesty was granted on 21 March.(IHT 23-03-98) 


\section{Sri Lanka}

In early October 1997 the government unveiled details of a power-sharing formula aimed at ending the country's ethnic war. The plans included the grant of greater autonomy in a regional council to the minority Muslim and Tamil communities in exchange for ethnic peace. It did not accept a Tamil demand for a union between the Tamil-dominated northern provinces and the multi-ethnic eastern provinces, but the government was prepared to hold a referendum on the question.(IHT 03-10-97)

On 22 February 1998 the Tamil rebels attacked a military ship convoy and sank two vessels.(IHT 24-02-98)

\section{Afghanistan}

(See also: Inter-state relations: general aspects: Iran-US)

In mid-August 1998 it was reported that the Taleban movement appeared to be on the brink of reunifying the country. They had overwhelmed the forces of the socalled Northern Alliance which had held on to much of the territory in the northern part of the country for two years, but were finally pushed back in two remaining redoubts, ending the civil war for all practical purposes.

Most states, and also the UN, maintained their recognition of the deposed president, BURHANUDDIN RABBANI, as the legitimate leader. The Taleban government was recognized by Pakistan, Saudi Arabia, and the United Arab Emirates.(IHT 13-08, 08-09-98)

[In 1973 the King as the last representative of the 250-year old DURRANI dynasty was ousted by a coup mounted by MOHAMMED DAUD, a cousin of the King. In April 1978 he was overthrown in turn and killed, in a military coup that brought the Communist Party to power. A civil war broke out, drawing in Soviet forces in February 1979.]

\section{DIPLOMATIC AND CONSULAR IMMUNITY AND INVIOLABILITY}

See: Inter-state relations: Afghanistan-Iran; (Non-)Intervention

\section{DIPLOMATIC AND CONSULAR RELATIONS}

See also: Inter-state relations: China-Liberia; Chin-Singapore; Iran-Europe; IranPakistan

\section{China-North Korea: consulate in Hong Kong}

China approved a request by North Korea to open a consulate in Hong Kong. North Korea had been lobbying for a consulate ever since the former British colony returned to Chinese rule in 1997. South Korea had not opposed the granting of the request.(IHT 15/16-05-99) 


\section{India-Pakistan}

In September 1998 India expelled a Pakistani diplomat for suspected espionage, and Pakistan retaliated with the expulsion of a member of the Indian High Commission in Pakistan for activities deemed incompatible with his diplomatic status.(IHT 05-10-98) Another case of mutual expulsion of diplomats took place in December 1998.(IHT 21-12-98)

\section{Iran-Argentina}

In 1992 there was a bombing of the Israeli embassy at Buenos Aires, and in 1994 another bombing took place directed against the Argentine Israeli Mutual Association, the city's main Jewish community centre. The Islamic Jihad, one of the armed groups linked to the Hezbollah organization in Lebanon, had claimed responsibility for the latter attack The Argentine government appeared to have accepted the long-held US and Israeli allegations that Iran had played a role in these incidents and, inter alia, ordered the expulsion of seven of Iran's eight embassy employees. It had also recalled all its diplomats from Iran with the exception of its chargé d'affaires. Both states had already withdrawn their ambassadors after the 1994 bombing. [See, however, the contrary news report in 5 AsYIL 402](IHT 18-05-98)

\section{Iran-United Kingdom}

The two countries which had severed their diplomatic relations ten years earlier after the religious death edict against the author SALMAN RUSHDIE announced the restoration of these relations at the level of ambassador. They had reached agreement on the matter in September 1998. With this restoration Iran regained diplomatic ties with all member states of the European Union.(IHT 19-05-99)

\section{Singapore-Andorra}

Singapore and Andorra established diplomatic relations on 18 September 1997. Many of Singapore's ambassadors do not live in the country to which they are assigned, but carry the title while remaining at home.(JP 20-09-97)

\section{South Korea-Russia}

In early July 1998 Russia expelled a South Korean diplomat accused of having bribed Russian officials for political and economic information.(IHT 06-07, 08-07-98) After a few days South Korea expelled a Russian diplomat. Both sides alleged that the expelled persons were working for the intelligence service of their respective countries.(IHT 09-07-98)

The dispute endangered the diplomatic relations established in 1990 between the two countries. 


\section{DISARMAMENT AND ARMS CONTROL}

\section{India}

The Indian prime minister in mid-December 1998 rejected three voluntary restraints on strategic weapons systems proposed by the US (on nuclear weapon deployment, on missile development and on production of bomb-grade material). Instead, his government would maintain the deployment of nuclear weapons, continue development of ballistic missiles and reserve the right to produce more bomb-grade material. The purpose of deployment of nuclear weapons was the "deployment of a deterrent which is both minimum and credible" and "ensures survivability and the capacity of an adequate response" in the event of a nuclear attack.

On the other hand, India would adhere to a comprehensive test ban before September 1999. It had already announced a voluntary moratorium on further tests. The prime minister also announced that India had tightened controls to prevent the export of technologies that could be used to make weapons of mass destruction.

Finally, the prime minister repeated that India was prepared to join negotiations on a Fissile Material Cutoff Treaty, but would not agree to cease producing bombgrade material until a non-discriminatory treaty had been finalized.(IHT 16-12-98)

\section{DIVIDED STATES: KOREA}

\section{US soldiers missing in action}

It was reported that an agreement was reached in May 1997 on exhumations of the remains of US soldiers missing in action at North Korean territory during the Korean War. Three rounds of exhumations would take place, starting in July.(IHT 01-07-97)

\section{North Korean defections}

According to South Korean officials, between 40 and 50 North Koreans had defected annually since 1994.(IHT 01-07-97)

It was reported that the North Korean ambassador to Egypt had defected in late August 1997, together with his wife, a famous actress. He was to return to North Korea in September 1997 after concluding his three-year term in Cairo. Earlier in the month his 19-year-old son had already disappeared.(JP 26-08-97) A South Korean foreign ministry official said that the ambassador's brother, then stationed in Paris, and his family, had joined the ambassador in an unidentified country.(JP 27-08-97) On 26 August the US announced that it had granted asylum to the ambassador and his brother.(JP 29-08-97)

\section{Four-party peace talks}

North Korea on 30 June 1997 agreed to the talks (see 7 AsYIL 417) by dropping its insistence on simultaneous food aid, clearing the way for preparatory talks to begin in New York on 5 August 1997. The talks would be the first between the South and the North to address directly matters like mutual recognition, normalization of 
relations, and eventual reunification.(IHT 02-07-97) When the preparatory talks had started, North Korea insisted on the unconditional withdrawal of foreign forces from the country be put on the agenda; it further demanded a cancellation of the scheduled US-South Korean military exercises.(IHT 08-08-97) It also accused the US of using economic sanctions as a means to turn the talks to its advantage. The talks thereupon broke off, but the parties agreed to resume them on 15 September.(IHT 9/10-08-97) Despite its displeasure at the asylum granted by the US to two North Korean diplomats (see infra at 282) North Korea agreed to stick to the agreed resumption.(IHT 12-09-97) The talks broke down again, however, because North Korea repeated its demand that any talks must include the issues of the withdrawal of the US troops and of food aid, accusing the US of using the food aid as a weapon in the talks.(IHT 22-09-97) After this demand as well as that on a separate peace accord between North Korea and the US were dropped (but this was denied by North Korea), the parties started the main negotiations on 9 December 1997 in Geneva. After a two-day session the next round of talks was fixed as being on 16 March 1998.(IHT 19-11, 22/23-09-12, 10-12, 11-12-97) In the ensuing negotiations North Korea kept insisting on having the issue of withdrawal of the US troops put on the agenda (IHT 21/22-03-98) which was rejected by the US.(IHT 23-03-98) The talks were resumed on 21 October 1998 for four days. Two working parties were to be created to explore a peace treaty and to examine confidence-building measures. A fourth round of talks was held in January 1999. Agreement was reached on procedures for the above working groups.(IHT 19-10, 26-10-98; 20-01 and 23/24-01-99) A following meeting was held in late April 1999, when the following issues were on the agenda: a communications channel between North and South Korean forces, the exchange of visits by officers, mutual advance notification of military exercises, setting up of a humanitarian corridor across the demilitarized zone.(IHT 26-04-99)

\section{Clash in demilitarized zone}

On 16 July 1997 a clash occurred in the demilitarized zone, leaving several North Korean soldiers wounded. A UN Command protest accusing the North of violating the armistice was delivered but rejected by North Korea. [North Korea had since June 1995 declined to recognize the armistice agreement, as its being a relic of the Cold War.](IHT 18-07-97)

\section{New attitudes on bilateral inter-Korean relations}

The new president-elect of South Korea proposed a broad dialogue with North Korea as the first step toward reconciliation, and said he might seek a summit meeting.(IHT 20/21-12-97)

On 19 February 1998 North Korea responded, by letters sent through Red Cross officials, with conciliatory gestures, also suggesting dialogue, including between political parties and civic groups.(IHT 20-02-98) A proposal by North Korea in early April to hold talks in Beijing on food and agricultural problems, the first bilateral talks in nearly four years (see 5 AsYIL 406), was accepted by South Korea; the talks started on 11 April. They covered a wide range of topics, but ended without results as the two sides focused on different matters: North Korea emphasized the food issue 
and South Korea stressed other issues, such as family reunions, exchange of envoys and the reactivation of a liaison office at the border village of Panmunjon.(IHT 06-04, 08-04, 13-04, 14-04-98) In an open letter dated 18 April the North Korean leader again called for a dialogue in a drive toward reunification. The two parties finally agreed to meet again on 21 June 1999, more than a year after the previous round. This was initially overshadowed by the naval incident that had just occurred (see infra) but the talks were later actually resumed.(IHT 30-04-98; 04-06, 21-06 and 25-06-99)

\section{Inter-Korean food aid}

Red Cross officials from the two Koreas began talks in Beijing on 22 December 1997 on food aid to the North. The South Korean Red Cross had given North Korea 100,000 tons of food aid in 1997. There would be a twomillion-ton shortage for the 25 million population in the coming year.

The most difficult aspect of the negotiations was guaranteeing the transparency of the delivery.(IHT 23-12, 24/25-12-97)

\section{Lifting of sanctions against North Korea}

The president of South Korea on 1 June 1998 called for the US to drop the existing economic sanctions against North Korea and replace them with a policy of increasing political "engagement". This would be part of a broad transformation of policy of the world toward North Korea which should lead to changes in North Korea and to its opening up.(IHT 02-06-98) [The above approach was part of the newly elected South Korean president's "Sunshine policy".]

\section{North Korean submarine in South Korean waters}

A North Korean midget submarine was snared in the nets of a fishing boat on 22 June 1998 at 18 kilometres off the east coast port of Sokcho, about 33 kilometres south of the North Korean border. This was just within South Korean waters and South Korean officials said it might have strayed off course.(compare 7 AsianYIL 415). The bodies of nine North Koreans were discovered inside the vessel.

There were indications that the vessel had been on a spy mission.(IHT 23-06 and 27/28-06-98)

\section{North Korean speedboat sunk}

A North Korean semi-submersible speedboat was sunk by South Korean warplanes and patrol boats on 18 December 1998 after being chased from the southern coast of South Korea into international waters.(IHT 19/20-12-98)

\section{Naval incident}

North and South Korean vessels confronted each other in a tense standoff on 9 June 1999, for the second day in a row, with each side accusing the other of intruding into its own waters. No shots were fired, but a South Korean boat collided with a North Korean one that it was trying to prevent from going farther south. Later in the week South Korean patrol boats rammed at least three North Korean vessels. 
According to the South Korean version of events, the episode began when North Korean military vessels headed in single file south of the "northern limit line". This is a line extending into the sea from the western end of the demarcation line between the two Koreas and established unilaterally by the "United Nations Command" after the Korea War to divide the waters to the west of the two Koreas. The line is not recognized by North Korea. The North Korean ships thus entered a South Korean "buffer zone" of two to 14 kilometres wide and escorted fishing boats which apparently were catching crabs that are bountiful on the southern side of the line. This crossing of the line in fact did occur periodically, but usually the North Korean ships left when ordered back by the South Koreans. According to the North Korean version of events the South Korean ships had intruded deep into North Korean waters but had fled when approached by North Korean ships.

On the following days North Korea continued sending groups of patrol boats south of the "northern limit line" into the crabbing zone while pulling out of the area before dusk.(IHT 10-06; 12/13-06 and 14-06-99) On 15 June 1999 military representatives of the US-led United Nations Command and North Korea met at Panmunjom for talks over the confrontation.(IHT 15-06-99)

On 15 June 1999 South Korean naval ships sank a North Korean gunboat during a furious barrage in the "buffer zone". The incident occurred when South Korean ships were ramming the North Korean vessels, trying to force them back to North Korean waters, when the North Koreans began firing.(IHT 16-06-99)

\section{EMBARGO}

\section{Supercomputers}

The US added thirteen foreign organizations, among which from Russia, China, India, Israel, and Pakistan, to a list of entities it contended of being involved in producing nuclear weapons and which require special federal approval to buy certain "supercomputers". This constituted a change in policy after relaxed export controls were introduced in 1995.(IHT 02-07-97)

\section{Lift of US embargo on China in exchange for support of embargo on Iran}

The US and China had concluded a nuclear cooperation agreement in 1985, but the US Congress, worried about Chinese sales of nuclear-weapons technology to Pakistan and Iran, passed a law that required the president first to certify that China had stopped such proliferation.

The US government told the US Congress in September 1997 that it was ready to certify that China had stopped exporting nuclear weapons technology to certain countries, which would allow the US nuclear energy industry to sell US nuclear power technology to China for the first time. It was reported that China had agreed to cancel or postpone indefinitely several projects at nuclear facilities in Pakistan and a "uranium conversion facility" in Iran, but had not agreed to a request to cease all nuclear cooperation with Iran. 
The planned policy decision might be related to a planned meeting between the US and Chinese presidents in October 1997.(IHT 19-09-97) The certification, with classified appendix, which was issued on 12 January 1998, read that China "is not assisting and will not assist any non-nuclear weapon state, either directly or indirectly, in acquiring nuclear explosive devices or the material and components for such devices".

In March 1998 it was reported China and the US once again reached agreement on the cancellation of another planned Sino-Iranian transaction on uranium-enriching chemical material, although according to the Chinese side the material concerned (anhydrous hydrogen fluoride) was not included in the lists of controlled chemical substances maintained by international arms control bodies.(IHT 14/15-03-98) However, Iran denied the cessation of its nuclear cooperation with China, alleging that its cooperation with other countries was of a peaceful character and in accordance with international regulations and under the supervision of the IAEA.(IHT 16-03-98)

\section{US purchase of goods in order to deny them to Iran}

The US bought advanced fighter planes from the former Soviet Republic of Moldova in order that they would not be bought by Iran.(IHT 06-11-97)

\section{US embargo on missile technology to Iran and Pakistan: Chinese position}

On the occasion of a visit by the US Defense Secretary in January 1998 China stated that it had ceased selling certain types of anti-ship cruise missiles to Iran. The US had objected to these sales because of its fears that the missiles could endanger free navigation in the Gulf shipping lanes. However, in November US officials raised concerns that China was continuing to transfer missile technology to other Asian countries such as Pakistan and Iran.(IHT 20-01 and 13-11-98)

[The technology concerned was listed in an annex of the Missile Technology Control Regime of which China is not a member. See 1 AsYIL 270; 2 AsYIL 349; 4 AsYIL 485; 5 AsYIL 468 and 6 AsYIL 431.]

\section{US embargo on weapon technology to Iran: Russia}

In late January 1998 the Russian government, pending formal legislation, introduced export-licensing restrictions to providing materials or technical services to foreign programs aimed at building missiles or nuclear, chemical or biological warheads.

For about a year alleged Iranian weapons programs had preoccupied the US, and under pressure from, inter alia, Israel, it had made intensive efforts to halt the flow of sensitive technologies from Russia.](IHT 26-01-98) It was reported in March 1998 that the US offered Russia the opportunity to expand the lucrative business of launching foreign satellites on condition that Russia took measures against the sale of missile technology to Iran.(IHT 10-03-98)

In July 1998 the US government stated it would impose trade sanctions on nine Russian companies and institutions that had helped Iran with missile development programmes. [The US president had just vetoed a bill for an Iran Missile Proliferation Sanctions Act that would impose sanctions on any company believed - "credible 
evidence" - to be aiding the missile, nuclear, or chemical weapons programmes of Iran. It was reported that the bill was strongly supported by the America Israel Public Affairs Committee.](IHT 17-07-98)

\section{US embargo on nuclear turbines from the Ukraine to Iran}

The US government blocked the provision of American nuclear technology and fuel to the Ukraine by Westinghouse Electric Corp. until the latter canceled plans to sell turbines to Russia (for the first Iranian nuclear power plant at Bushehr). It did so by offering the Ukraine, by way of compensation, a package of loans, credits and joint ventures, along with military and space cooperation and the prospect of future access to US nuclear fuel. If, however, the turbine deal went forward, the US would refrain from signing an accord on peaceful nuclear cooperation. (See: 5 AsYIL 477; 6 AsYIL 436; 7 AsYIL 467). [The cooperation agreement was concluded on 6 March 1998 and the delivery of the turbine was canceled] (IHT 09-02-98)

\section{Iranian acceptance of international safeguards and US position}

It was reported that Iran had promised to accept international safeguards against nuclear proliferation at its Bushehr plant, but that the US government contended that the plant was related to a secret Iranian plant to develop nuclear weapons.(IHT 09-0298)

\section{US embargo on satellite sales to China}

The US decided to reject the sale of a satellite to a Singapore-based consortium that was considered as having close ties with the Chinese government, thus reversing both an approval of two and a half years earlier and a policy that had been in effect for several years. It was said that the sales could threaten US security and increase the military capability of China. The satellite in question was designed to set up a mobile telephone network over a large part of Asia.(IHT 24-02-99)

\section{ENVIRONMENTAL POLLUTION AND PROTECTION}

\section{Waste imports from Europe}

It was reported that at least 200 cases of plastic waste had been illegally imported into Indonesia from Germany since the middle of August 1997, giving rise to demonstrations by environmentalists in front of the German embassy at Jakarta.

The transport of hazardous waste from industrialized countries to developing countries is prohibited by the Basel Convention unless unless, firstly, permitted by the receiving state and secondly, there is the availability of proper storage capacity. Indonesia had already prohibited the import of (noxious) so-called "B3" waste, particularly plastic waste.

The import into Indonesia of B3 waste had been noticed since 1990. In 1995 the Netherlands, as one of the countries of origin, took back 75 cases.(Kompas 17-0997) 


\section{Transboundary effects of Indonesian forest fires}

Forest fires on the islands of Sumatra and Kalimantan as a result of "slash and burn" methods employed by private enterprises to clear the land for other purposes affected not only areas in Indonesia but also in Singapore, Malaysia, and Brunei. The meeting of ASEAN environment ministers in mid-September 1997 was overshadowed by the "haze" problem. The Indonesian president apologized for the problem to the neighbouring countries.(Kompas 17-09-97)

On 20 September 1997 Malaysia pledged to send firefighters to help Indonesia in fighting the fire. It also pledged to help Indonesia to seed clouds over Kalimantan in a bid to cut the choking smoke with artificial rain.(JP 21-09-97) More than a dozen countries contributed to efforts to fight the brush and forest fires, among which were Germany, Australia, Japan, South Korea, Canada, the UK, the US, Norway, Finland, France, Sweden, Switzerland, Thailand, and Singapore, as did UN agencies such as the WHO and the UNDP. Assistance was also pledged by the UN Disaster Assessment and Coordination Team.(JP 03 and 08-10-97)

The ASEAN ministers revealed a regional plan on 23 December 1997 to try to prevent a recurrence of the smog generated by the Indonesian forest fires.(IHT 24/2512-97)

\section{Singapore's accession to 1992 Protocol to the 1969 Civil Liability Convention}

Singapore signed the 1992 Protocol to the 1969 Convention on Civil Liability for Oil Pollution Damage. This would result in oil spill compensation cost four times the existing rate. By so doing Singapore was taking responsibility for ensuring that Singapore-registered oil tankers would be covered by insurance for a higher limit of compensation. This was a consequence of positioning itself as Asia's maritime hub and taking a lead role in the region. The previous limit had been inadequate for some time, bearing in mind the devastating exposure Singapore was facing to oil pollution.(JP 22-09-97)

Not being a party to the 1971 International Oil Pollution Compensation Agreement ("Fund Convention") Singapore, in contrast to Malaysia and Indonesia, would not be compensated for the oil spill as a result of the collision on 15 October 1997 between the Cyprus-registered tanker Evoikos and a Thai-flagged, empty, very large crude carrier (VLCC), the Orapin Global. The wind direction would have been a crucial factor in the environmental damage resulting from the spilling of 25,000 tons of fuel oil..

There had been intensive discussions within the framework of the IMO on preventing oil spills in the Southeast Asian region, among which was a proposal to divert shipping further south and away from the shallow and narrow Singapore Strait, adding two days' journey for a tanker bound for Japan, moving the problem elsewhere rather than solving it.(IHT 17-10-97, JP 20-10-97)

\section{UN Climate Change Convention: Asian attitudes}

The 1992 Rio Convention had called for states parties to reduce emissions of greenhouse gases by the year 2000, reverting to the levels of 1990 . A conference in Berlin in 1995 said stronger measures should be taken. It mandated a working 
group to come up with an amendment or treaty for further commitments. The US, Europe, and Japan differed over what these should be.

The EU had proposed mandating a reduction of 15 per cent of the 1990 levels by 2010. It was backed by the Group of 77 and China, all of whom refused to be forced to match the industrialized countries in anti-pollution measures that could hinder development. Japan proposed a five per cent reduction from the year 2008 to 2012 , with the possibility of further modifications. The US wanted to delay the reductions in emissions below their 1990 levels until after 2012. This would give the US two decades, i.e. until 2017 to bring emissions to levels below those set in 1990. The US president made US engagement in cutting greenhouse gases conditional on pollution limits in the developing world.(JP 01-11-97)

Countries would, however, be able to reduce that target if their 1990 emissions per gross domestic product were lower than the average, or if their population growth rate were lower than the average.

At a conference held on 1-10 December 1997 in Kyoto, Japan, the signatories to the 1992 UN Climate Change Convention decided on targets for industrialized countries to cut emissions of greenhouse gases in the twenty-first century. The particularly heated argument between China and the US resulted in the Chinese success in exempting itself and the rest of the developing world from commitments to cut emissions, and the Americans succeeding in establishing the right of so-called "emissions trading", although disagreement remained on whether this right should be limited (the issue of a so-called "cap").(JP 07-10 and 12-12-97)

According to IEA data the US produced 23.7 per cent of total $\mathrm{CO} 2$ emissions or 20 tons per capita annually; China, 13.6 per cent or 2.51 tons on a per capita basis; Russia, seven per cent; Japan, 5.2 per cent and Germany, four per cent.(JP 15-11-97)

\section{GROUP OF 15 DEVELOPING NATIONS (G-15)}

\section{Its genesis, purposes and activities}

The Group was set up as a result of a meeting to discuss common problems, convened by Malaysia in 1990 in Kuala Lumpur, of fifteen developing countries. The Group consists of Algeria, Argentina, Brazil, Chile, Egypt, India, Indonesia, Jamaica, Malaysia, Mexico, Nigeria, Peru, Senegal, Venezuela, and Zimbabwe. At the Group's seventh annual summit meeting in early November 1997 Kenya was admitted as its sixteenth member.(IHT 04-11-97;JP 01-11-97) Although Latin America was meant to be the original engine for the G-15 as it was the region that had stable leadership and had earlier liberalized, the Group's cohesiveness was, in fact, undermined by the interest of Latin America in its own regional integration.(JP 07-11-97)

At the meeting of foreign ministers preceding the seventh summit at Kuala Lumpur in 1997, the low attendance at the summit meetings was a point of discussion. The 1994 summit had even had to be cancelled due to its being inquorate. The G-15 countries were divided over whether to hold summits every two years instead of 
annually. Many G-15 projects were progressing rather slowly, mainly due to problems of funding, information and coordination.

In a bid to increase economic cooperation, the group held its first meeting of trade and economic ministers on 31 October 1997.(JP 02-11-97) The Group also asked the WTO to study the impact of currency fluctuations on trade but stopped short of endorsing a call by Malaysia for rules on foreign-exchange trading.

The three-day summit ended with an agreement to meet more often to improve the coordination of positions. The next meeting would [and did] take place in Cairo in May 1998. (IHT 01/02-11-97;JP 06-11-97)

\section{HIGH SEAS}

\section{Freedom of navigation}

See: Regional security

\section{HONG KONG}

\section{Resumption of Chinese sovereignty}

China resumed sovereignty over Hong Kong on 1 July 1997. Sovereignty was wrested from China 156 years ago by Britain, intent on selling opium to the Chinese.(IHT 01-07-97)

\section{HUMAN RIGHTS}

\section{Review of the UN Declaration on Human Rights}

On the occasion of the ASEAN foreign ministers' conference in July 1997 the Malaysian prime minister raised the idea of a review and possibl change of the 1948 Declaration in order to take account of the views of developing countries. He was quoted as saying that the West's insistence that developing countries conform to its high ideals on human rights as a form of oppression. The Declaration was issued at a time when most of the current UN members had not yet gained statehood and independence from colonial rule.

At the meeting to which non-ASEAN ministers were invited, the idea obtained support from the non-Western participants present. On the other hand, the representatives of the European Union and the US were strongly against. A EU representative said the EU would be "extremely reluctant" to embark on a review, as it regarded the declaration as "one of the cornerstones of the international legal and political system". The US Secretary of State said that the US would be "relentless" in its opposition to any attempts to change the Declaration.(IHT 29-07,30-07-97) 


\section{UN access to political prisoners in China}

For the first time UN experts, members of the UN working group on arbitrary detention, had private interviews with political prisoners in China.(IHT 22-10-97)

\section{UN resolution on human rights in China}

The US dropped its sponsorship of a (since 1990 practically annual) draft UN resolution condemning China's record on human rights. This was seen as a response to what were considered Chinese efforts to improve its record, including the recent decision to join the UN Covenant on Civil and Political Rights.(IHT 16-03-98)

\section{IMMIGRATION}

See: Refugees

\section{INSURGENTS}

\section{Cease-fire in Philippine insurgency}

The Philippine government and the Moro Islamic Liberation Front signed a ceasefire agreement on 18 July 1997, paving the way for formal peace talks.(IHT 19/20-0797)

\section{Accord between Philippine government and Communist insurgents} (See also: 7 AsYIL 430)

Agreement was reached in early February 1998 in the Netherlands, where the talks had been proceeding sporadically since 1992,on an accord, the "Comprehensive Agreement on Respect for Human Rights and International Humanitarian Law", together with two related agreements. The accord was signed in March 1998, the first of four agreements forming a political settlement ending a nearly-three-decade insurgency.(IHT 03-02 and 17-03-98)

However, in early 1999 several abductions were carried out by the New People's Army, the military arm of the Communist Party, resulting in the Philippine president suspending the peace talks.(IHT 24-02 and 25-02-99)

\section{Shanti Bahini in Bangladesh}

(See also: 4 AsianYIL 452, 7 AsianYIL 431)

A twenty-two-year separatist war was ended on 2 December 1997 with the signing of an accord between the government and the Shanti Bahini rebels. The Shanti Bahini had been fighting a war since 1973 over demands for autonomy for the Hill Tracts in the northeastern Indian state of Tripura, bordering Bangladesh. The region in question has an area of 13,000 square kilometres southeast of Dhaka and a population of 800,000 people, and the rebels were mainly from the predominantly Buddhist Chakma tribe. Under the agreement there would be three elected district councils which would control the land management and local police of the area. The first batch 
of insurgents in the southeastern Chittagong Hill Tracts were to give up their weapons in February 1998.(IHT 03-12-97 and 16-01-98)

The agreement gave rise to protests from the political opposition; they held that the accord gave the Buddhist rebels too much power at the expense of Muslim Bengali-speaking settlers from the north who would have to return their land to the tribes, and that it in effect handed over the Chittagong Hill Tracts to India.(JP 17-1097;IHT 11-06-98)

\section{Bougainville peace efforts}

The Papua New-Guinea (PNG) prime minister in late August 1997 gave full government support for the Burnham (New Zealand airbase) Peace Declaration to end the nine-year secessionist war. The declaration was agreed by the rebel representatives and the PNG government-backed Bougainville Transitional Government. The declaration called for a cease-fire, demilitarization, an end of the military blockade and the installation of a UN peace-keeping force.(JP 25-08-97) An interim truce agreement was signed on 10 October 1997.

The conflict began when in 1988 landowners revolted over damage caused by the huge Panguna copper mine and the level of royalties they received from it. The mine, since closed, was owned by a unit of the Anglo-Australian Rio Tinto Ltd.(JP 11-10-97)

New Zealand was to lead an unarmed Truce Monitoring Group, including representatives from Australia, Fiji, Tonga, and Vanuatu. It would be neither a military peace-keeping nor a peace-enforcing body.(JP 18 and 19-11-97)

\section{Insurgents' attack on foreign vessel in Sri Lanka}

Tamil Tiger guerrillas set ablaze a Chinese cargo carrier on 9 September 1997 while it was loading cargo at a government-owned mineral sands facility. The attack was the second against a foreign ship at the same port: in August 1996 a Philippineregistered ship was the target.

In July 1997 the LTTE hijacked a North Korean cargo vessel, later freed. The guerrillas then vowed to attack merchant vessels taking supplies for the government to the Tigers' former stronghold in the north of the island.(JP 10-09-97)

A shipment of mortar bombs from Zimbabwe for the Sri Lankan government went missing in July 1997 and according to the Zimbabwean side the weapons were captured by the insurgents. The latter denied the charges, charging that the allegation was aimed at tarnishing their image and associating them with acts of piracy.(JP 0610-97)

\section{INTER-STATE RELATIONS: GENERAL ASPECTS}

\section{Afghanistan-Iran}

As forces of the Taleban advanced in northern Afghanistan, Iran had asked them, through the Pakistan embassy, whether the safety of the Iranian consulate in the city of Mazar-i-Sharif could be guaranteed as and when the Taleban captured the town. 
The answer was in the affirmative, but in reality a great number of Iranians were in August 1998 caught up in the fighting. Eleven Iranian diplomats disappeared in the event. Iran reacted angrily and raised the prospect of military action. The leader of the Taleban, which had taken over authority of virtually the whole country, said that the diplomats were "probably dead"; this was confirmed on 9 September in respect of nine of them.

The Taleban put the blame on renegade fighters acting without orders, yet Iran put responsibility for the "abhorrent killing" squarely on the shoulders of the Taleban along with Pakistan, which had "assured us of their safety". Taleban officials promised to punish the soldiers who had carried out the executions, but rebuffed both an Iranian demand that those responsible be handed over to the Iranian authorities or to an international tribunal, and to issue a formal apology. The case was brought before the UN Security Council.

On the other hand there were ample suspicions that Iran had been active in assisting Shiite anti-Taleban alliances.(IHT 07-09;11-09;12/13-09 and 17-09-98)

A first border clash took place on 8 October 1998.(IHT 09-10-98)

\section{Asia-Europe Meeting (ASEM)}

(See also: 6 AsYIL 401)

The UK had accused Myanmar of profiting from the drug trade and announced that it would not be admitted to the 1998 Asia-Europe Meeting. The UK could bar Myanmar from the gathering because it constituted a voluntary dialogue between individual states rather than a bloc-to-bloc meeting. By way of response a senior Myanmar official recalled that 150 years ago Britain had forcefully introduced opium into Asia.(IHT 02-09-97)

The second Asia-Europe meeting was held in London in early April 1998. It was attended by twenty-five heads of state or government. The next meeting would be held in Seoul in 2003.(IHT 03-04 and 06-04-98)

\section{Asian attitudes toward the Iraq issue}

The conflict over Iraqi behaviour toward the activities of the UN Special Commission had led the US to carry out heavy missile attacks and air strikes on Iraqi targets in mid-December 1998. Japan issued a forthright defence of the American action, while the Chinese response consisted of a sharply worded attack on the US. Singapore showed increasing support for the US position, and the Malaysian prime minister denounced the US action. South Korea uttered modest rhetorical backing.(IHT 21-1298)

\section{Cambodia-Japan}

(See: Civil war: Cambodia)

\section{Cambodia-Vietnam}

The leader of the Vietnamese Communist Party paid a state visit to Cambodia, aiming at easing historically tense relations.(IHT 10-06-99) 


\section{Cambodia-Thailand}

As a result of the battle between Cambodian factions near the Thai border, artillery shells hit Thai territory, killing a Thai soldier. The Thai army retaliated and the Cambodian government apologized for the accident. The Thai premier acknowledged that it was an accident, stressing that Thailand would remain neutral and would not intervene in the internal conflict.(JP 29-08-97)

\section{China-ASEAN}

During a visit to Malaysia in August 1997, the Chinese prime minister put forward a five-point proposal on developing relations between the two sides: respecting each other and treating each other as equals; strengthening dialogue and intensifying consultation; seeking common development based on mutual benefit; supporting each other and expanding cooperation; bearing in mind the general situation, seeking common ground while setting aside differences.(JP 01-10-97)

\section{China-India}

(See also: Weapons: Indian nuclear weapon test)

During a television interview on 3 May 1998 the Indian defence minister declared that China, not Pakistan, is India's "potential threat No.1", referring to Chinese "encirclement" and assistance to Pakistan. Later he softened his pronouncements by saying that he had been misunderstood and that he was committed to dialogue.(IHT 04-05;06-05 and 07-05-98)

\section{China-Japan}

In talks between the Chinese and Japanese foreign ministers the Japanese side promised to be more open about its security pact with the US [see infra at 290].(IHT 01-07-97)

The president of China paid a five-day state visit to Japan in late November 1998. (IHT 26-11-98). He was the first Chinese head of state ever to visit Japan.

The visit was somewhat overshadowed by certain disagreements. The joint declaration was released without signatures. China wanted two concessions: a clear-cut written apology for the behaviour of Japan during World War II, similar to that given to South Korea (see infra at 281), and a pledge about relations with Taiwan similar to the three "no's" by the US president (see infra at 276). Japan rejected both wishes and offered a verbal apology only. The Japanese government explained this apparent anomaly by saying that the historical circumstances were different, such as in the fact that Japan had formally annexed the Korean peninsula while in the case of China, Japan had fought a war there; this was an act for which Japan had to apologize yet not in writing although the essence was the same. Further, the Japanese emperor had already been to China and had expressed deep regret for the war.

The written joint declaration contained the following statement: "Japan feels acute responsibility for the grave misfortune and harm to the Chinese people during a certain period of aggression toward China, and we express deep remorse about this." As to the fact that the written joint declaration did not contain signatures, it was said that the document was never intended to be signed. 
As to the issue of Taiwan: the Japanese prime minister stated that he did not support Taiwan independence and did regard it as Chinese territory.(IHT 27-11 and 30-11-98)

\section{China-Liberia}

China severed its diplomatic relations with Liberia on 9 September 1997 because Liberia had established official relations with Taiwan.(IHT 10-09-97) In this context the Liberian consulate in Hong Kong was also closed.(IHT 10-10-97)

\section{China-Russia}

The Russian president paid a state visit to China in November 1997. The summit meeting resulted in agreements on various topics, such as border demarcation (see: Borders), cooperation between border regions, technical and scientific cooperation, cooperation on regulating trade in financial services, the diamond trade, oil and gas, and protecting the Manchurian tiger.

China and Russia, inter alia, signed a framework agreement to construct a $\$ 12$ billion, 3,000-km-long pipeline from Siberia to North China. It was hoped that Japan and South Korea would join in the financing, in return for some of the 20 billion cubic metres of gas that would flow down the line.

The Russian president characterized the Sino-Russian ties as "a strategic partnership based on personal trust between the presidents of China and Russia".(IHT 11-1197;JP 11-11-97)

\section{China-Singapore}

For the first time since the establishment of diplomatic relations in 1990 (as to the timing of establishing these relations Singapore had ceded precedence to its larger neighbour, Indonesia), the Chinese premier visited Singapore in August 1997.(JP 27-08-97)

\section{China-Southeast Asia}

The Chinese response to the seizure of power in Cambodia by Mr.HUN SEN (see: Civil War) was considered to mark a major change in Chinese policy toward the region. Whereas it launched a reprisal attack into Vietnam when Vietnam invaded Cambodia in 1978 to oust the Khmer Rouge, its recent stance was very restrained. Southeast Asian officials said China was willing to let countries in the region take the lead on matters affecting regional stability. Its backing for the ASEAN efforts to broker an end to the political crisis in Cambodia would also help to ensure that those efforts were not pushed aside by the more powerful efforts of the US.(IHT 25-07-97)

\section{China-US}

(See also: Law of armed conflict)

China urged the US on 15 July 1997 to reject a transit visa request from the president of Taiwan, warning that issuing the visa could seriously damage Sino-US 
ties.(IHT 16-07-97) A visa was nevertheless issued for two transits at Honolulu.(IHT 01-08-97)

The Chinese president paid an official to the US in late October 1997, the first Sino-US summit in twelve years.(IHT 27-10-97) The two sides afterwards issued a joint statement.(IHT 04-11-97) On his part the US president paid a visit to China in late June 1998.(IHT 25-06-98)

During his visit the US president declared that the US does not support an independent Taiwan, will oppose Taiwan's entry into organizations of nation-states and does not support a policy of "one China, one Taiwan". The statement became known as the "three noes" policy. The president said that the US supported the peaceful reunification of China and Taiwan. He did not make direct mention of China's demand that the US begin winding down arms supplies to Taiwan, but did say, at another meeting, that "our policy is that weapons sales to Taiwan are for defensive purposes only".(IHT 01-07-98)

As well as US plans to develop a national system of missile defence, it was reported in January 1999 that the US was preparing plans for a missile system to defend Japan, South Korea, and Taiwan, including the US troops stationed in the region. The idea of constructing such a system became more acute with the North Korean firing of a missile or rocket into the Pacific Ocean in August 1998. (see infra at $\mathrm{xxx}$ ) [Russia was worried that the US project for a limited missile shield would imply revising the 1972 Treaty on anti-ballistic missiles, but the US had sought to assure Russia that the US would not withdraw from the ABM commitments.(IHT 12-03-99)]

When US-Japanese discussions about the plans were publicized China accused the US of trying to start "a revival of Japan's military ambitions". As regards Taiwan, any system aimed at protecting the island would imply its being aimed at neutralizing the existing Chinese missiles facing Taiwan. China said that the system "would only undermine security and stimulate the proliferation of missiles", and that it struck at US ties with China as enshrined in the well-known three joint communiques, under which the US agreed to sell only defensive weapons to Taipei.(IHT 23/24-01;2501;11-02 and 12-02-99) The Chinese foreign minister also warned that a theatre missile defence system would amount to an encroachment on China's sovereignty and territorial integrity and would block hopes of a peaceful reunion of the mainland with Taiwan.(IHT 08-03-99)

In its first concrete response to increasing deployment of missiles by China in coastal areas the US allowed Taiwan to buy an early-warning system from the US. A US official acknowledged that one purpose of the approval was to try to dissuade China from continuing its build-up of missiles and manned bombers across the Taiwan Strait.(IHT 02-05-99)

Reportedly in a gesture of goodwill toward China the US military commander in Asia and the Pacific in late May 1999 urged stronger multilateral security arrangements in the region, a measure long demanded by China to reduce the dominant role of US bilateral alliances with Japan, South Korea, Thailand, the Philippines and Australia. In the Chinese view these alliances are aimed at containing China and should be abandoned in favour of broader cooperative security arrangements. The 
commander linked the effectiveness of such arrangements with the settlement of disputes such as those over the Spratly Islands.(IHT 24-05-99)

\section{India-Pakistan}

(See also: Specific territories within a state: Kashmir)

In his speech to the UN General Assembly the Pakistan prime minister on 23 September 1997 made a proposal to open talks on a non-aggression pact with India and for the two countries to show "mutual and equal restraint in the nuclear and ballistic fields". However, the two sides had already agreed in 1972 to settle their differences peacefully, and in 1988 signed an agreement not to attack each other's nuclear plants. After the third Indo-Pakistan war the two sides met in 1972 at Simla and agreed to "refrain from the threat or use of force against the territorial integrity or political independence of each other". On the other hand, there have been Indian proposals since 1994 to extend the nuclear agreement to population centres and economic targets, and to reach a no-first nuclear strike agreement.(JP 24-09-97)

The two states held three days of peace talks in September 1997, agreeing to meet again, but without signs of progress. It was the third round of negotiations since March 1997. (IHT 19-09-97;JP 17-09 and 18-09-97) On 29 July 1998 the two prime ministers met on the sidelines of the annual SAARC summit conference, for the first time since the nuclear tests conducted by both countries in May of that year (see: Nuclear energy matters). It was agreed that the above talks would be resumed, but the preparatory talks over procedures of the talks ended in failure.(IHT 30-07 and $1 / 2$-08-98) When the two prime ministers met in September 1998 during the meeting of the UN General Assembly session they agreed to resume the talks. The most extensive Indo-Pakistan discussion ever on nuclear weapons issues was then held in three days of talks in mid-October 1998, inter alia, on confidence-building measures. The parties agreed to meet again in February 1999.(IHT 17/18-10 and 1910-98)

This meeting of 20-21 February 1999 was described as the "most historic engagement" between the two countries since their Simla Peace Agreement of 1972. It took place in Lahore, Pakistan, where the Indian prime minister arrived by bus on the inaugural run of a cross-border bus service, as the first Indian prime minister in ten years to visit Pakistan.(IHT 19-02-99)

The meeting resulted in several agreements, as embodied in a joint statement, the "Lahore Declaration". The parties would reduce the risk of nuclear war on the subcontinent by exchanging strategic information about their arsenals and giving each other advance notice of ballistic missile tests. Similarly, notice would be given of "any accidental, unauthorized or unexplained incident" that could create the risk of nuclear fallout or an outbreak of nuclear war. They pledged to "engage in consultations on security concepts and nuclear doctrines, with a view to developing measures for confidence building in the nuclear and conventional fields", aimed at the avoidance of conflict. They also pledged to intensify their efforts to resolve their differences, such as the Kashmir dispute, and to have periodic foreign ministerial meetings.(IHT 22-02-99) 


\section{Iran-Arab countries}

As an effort to improve ties between the two states an envoy from Saudi Arabia paid a rare visit to Iran in early July 1997.(IHT 02-07-97)

Against the backdrop of an often disharmonious relationship between Iran and other Arab countries, mending these relations had been going on for a while and the process accelerated in 1997 with the election of the new Iranian president. There was, inter alia, a flurry of diplomatic traffic between Iran and the Gulf states. In May 1999 the Iranian president went on a tour of Arab countries. He began his trip in Syria then started his visit to Saudi Arabia on 14 May 1999, the first Iranian leader to visit Saudi Arabia in twenty years. The trip was continued with a visit to Qatar.(IHT 15/16-05-99)

\section{Iran-Europe}

The ambassadors of all but one of the European Union countries had been recalled in connection with the Mykonos case (see 6 AsYIL 422; 7 AsYIL 408;453). It was reported that the fifteen EU states had agreed in principle on 5 September 1997 to send their ambassadors back to Iran, but no progress was achieved on resolving the Iranian demand that the German ambassador be the last EU envoy to return.(JP 04-1097)

Iran considered the crisis with Germany to be of a "bilateral nature" which ought be settled through bilateral talks. On the other hand, the German foreign ministry said that Germany would hold talks only once the EU ambassadors were back in Tehran.(JP 06-10-97)

\section{Iran-Pakistan}

Unidentified gunmen had shot dead four Iranian air force personnel and their Pakistani driver in Rawalpindi. The Iranians were receiving technical training in Pakistan. The incident came after several attacks on Iranian interests in Punjab Province where clashes between Sunni and Shia Muslim factions were not unknown. The Iranian foreign ministry summoned the Pakistani ambassador for an explanation. The ambassador expressed regret over the incident.

Apart from the incident referred to above, a Sunni militant group had earlier claimed responsibility for the killing of an Iranian diplomat in February 1997, and in January 1997 a Sunni Muslim mob had burnt down an Iranian cultural centre in Lahore.(JP 18-09-97)

\section{Iran-Thailand}

The Iranian foreign minister warned that relations with Thailand could suffer if Thailand did not release an Iranian sentenced to death in Thailand for plotting to bomb the Israeli embassy. Iran was of the opinion that the man was not guilty and had been arrested by mistake.

A Thai appeals court upheld the death sentence in June 1997.(JP 17-09-97) 


\section{Iran-US}

There were essentially three points of contention between the US and Iran: (i) the Palestinian issue, (ii) the allegation that Iran was a supporter of terrorist activities, and (iii) the US accusation that Iran was pursuing programmes to develop nuclear, chemical and biological weapons and the disapproval of the US of the pursuits of Iran in the field of ballistic missiles.

It was reported that the US was quietly seeking to improve its relations with Iran. This occurred against the backdrop of what was considered a political shift in Iran, symbolized by the outcome of the presidential election in May 1997.(IHT 10-07-97) At the Organization of the Islamic Conference (see infra at 302) on 15 December 1997 the newly elected Iranian president called for renewed "thoughtful dialogue" with "the great people and nation of America". The suggestion was repeated later in an interview with CNN. The US responded positively, although it was divulged later that just after the new president's inauguration in August 1997 the US had already conveyed a proposal through diplomatic channels for open direct talks.(IHT 16-12-97;08-01;09-01 and 10/11-01-98) It was also reported that since the new Iranian president had taken office there had been low-key US-Iran deliberations in a small group of UN member states, among whom were Russia, Turkmenistan, Uzbekistan, Tajikistan, Pakistan, and China, to explore ways to end the civil war in Afghanistan.(IHT 16-12-97)

In the first significant easing of the US economic isolation of Iran [among the Iranian grievances was that concerning the Iranian assets frozen in the US immediately after the Islamic revolution of 1979] the US government decided in July 1997 not to oppose a 3,200-kilometre pipeline that would carry Central Asian natural gas across Iran to Turkey. The project was considered not to be in violation of the US 1996 Iran-Lybia Sanctions Act which prohibited investments of more than $\$ 40$ million in the development of Iran's energy sector.(IHT 28-07-97) (see also: Oil and gas) However, later in the year the US sought to persuade Caspian Sea states to scrap plans for oil and gas pipelines through Iran in favour of a more costly "Eurasian transportation corridor" to the West. Although the real choice depended on a decision from the oil companies, leaders of the region (Azerbaijan, Georgia, Turkey, Kazakhstan, and Uzbekistan) on 29 October 1998 "strongly confirmed their determination" to realize the American-backed pipeline route, increasing political pressure on the companies.(IHT 21-11-97 and 30-10-98)

In June 1998 the US government declared it was seeking "a genuine reconciliation" with Iran but repeatedly linked Iran with the support of terrorism and distribution of dangerous weapons as well as with opposition to the peace process in the Middle East. On the other hand the Iranian side urged the US to end its "hostile policies" toward Iran before any normalization could occur, and called for the US to end support for opponents of Iran based in Iraq, to free Iranian assets frozen two decades ago and to "apologize to the Iranian nation for its wrong policies in the past fifty years".

The evolving relationship since January 1998 showed the promotion of cultural exchanges, the relaxation of travel restrictions on Iranian diplomats and eased entry barriers to visiting Iranians.(IHT 19-06-98) 
Responding to a US call to join in drawing up a roadmap to normal relations, the Iranian foreign minister in a speech to the Asia Society in New York acknowledged a "new tone" toward Iran on the part of the US but said that "sole reliance on variation of verbiage can simply not provide the necessary basis for an invitation to political dialogue". He made the following criticisms: (i) the US lacks "a commitment to international law" because of its imposition of sanctions against Iran and dozens of other countries; (ii) the US is "retarding economic prosperity of Iran and the region" by its policy of obstructing the building of a pipeline through Iran from Central Asia and the Caucasus; (iii) the US is trying to “sabotage" Iran's efforts to play a role in promoting regional stability, and (iv) the covert programme approved by the US Congress to destabilize Iran and the recent creation of a Persian-language radio station to wage a propaganda war against Iran are evidence of American interference in internal affairs of Iran.(IHT 30-09-98) On 3 November 1998 the Iranian supreme leader ruled out any possibility of a normalization of relations with the US.(IHT 04-11-98)

It was reported that the US had been pressing Russia for most of 1997 to stop its scientists and military institutes from helping Iran develop a new ballistic missile with a range of between 683 and 1,243 miles, one that could reach Israel, Saudi Arabia and US troops in the Gulf area, but Russian officials had denied any government policy or program to that effect. It was reported that the missile issue had become a major one as Israel had stepped up its charges on the matter.

US officials estimated that deployment of the missiles concerned could be between two and five or more years away, depending on how much help Iran would receive from countries like Russia, China and North Korea.(IHT 23/24-08, 22-09-97)

The annual report of the US State Department had referred to Iran as remaining "the most active state sponsor of terrorism". Iran rejected the accusation and through the state-run radio said, inter alia: "Itself a major victim of terrorism, Iran is fully aware of the dangers of this phenomenon and has worked with other countries at international bodies to rid the world of this threat."(IHT 02/03-05-98)

\section{Japan-North Korea}

(See also: Nuclear capability; Missile technology; Territorial sovereignty)

North Korea announced in July 1997 it would lift a ban preventing Japanese women who were married to North Koreans from leaving the country to visit their homeland. There were an estimated 1,800 of them who had married their Korean husbands in Japan and followed them to North Korea between 1959 and 1982.(IHT 18-07-97) On the other hand, Japan refused to send food aid until it obtained information about the alleged abductions of up to 19 Japanese citizens by North Korean agents in the course of the past decades.(IHT 04-08-97) North Korea and Japanese Red Cross officials signed an agreement on 9 September 1997 allowing the visit to Japan of Japanese wives of North Koreans (see above)(IHT 10-09-97) A month later it was reported that Japan had resumed its food aid.(IHT 10-10-97)

However, in June 1998 North Korea announced that it had conducted an exhaustive search for the Japanese persons who had allegedly been abducted but had found no sign of them. When Japan refused to accept this information North Korea 
cancelled the planned visit by Japanese-born wives of Koreans to Japan.(IHT 10-0698)

In August 1997 Japanese negotiators held talks with North Korean counterparts at Beijing aimed at restarting efforts to normalize diplomatic ties. These normalization talks had been stalled for nearly five years.(IHT 21-08-97) In November 1992 eight rounds of similar talks ended abruptly when North Korea broke off negotiations after the Japanese side raised allegations that North Korean agents had kidnapped Japanese nationals. This referred to the abduction on seven occasions involving ten Japanese in the 1970s and 1980s.(IHT 22-08-97)

At the invitation of the ruling party in North Korea the Japanese governing parties were to send a mission to Pyongyang to prepare a resumption of talks on normalizing diplomatic relations.(IHT 04-11-97)

\section{Japan-Russia}

The Japanese prime minister and the Russian president held a summit meeting at Krasnoyarsk, Siberia, on 2 November 1997. They pledged to make maximum efforts to conclude a peace treaty by the year 2000 . Despite a normalization of relations in 1956 a peace treaty had not yet been concluded, particularly because of the ongoing dispute over the Kuril Islands ("Northern Territories" to Japan) seized from Japan near the end of World War II.(IHT 03-11-97)

\section{Japan-South Korea}

During a state visit by the South Korean president to Japan in early October 1998 the emperor and the Japanese prime minister offered frank and unambiguous apologies for the suffering that Japan had caused during its 1910-1945 occupation of the Korean Peninsula. The apology was contained in a joint declaration, the first written apology issued to an individual country by Japan for its actions before and during World War II.

On his part the Korean president in a speech to the Japanese Parliament forgave Japan for its behaviour and emphasized a future of partnership. He said, inter alia: "It is truly infantile to regard 1,500 years of exchanges and cooperation as insignificant because of unfortunate periods that totaled fewer than fifty years", and "Isn't it something we should be ashamed of and something we should be reproached for by our ancestors, who forged such a history ...?" He stressed reconciliation and future cooperation.(IHT 08-10 and 09-10-98)

The Japanese prime minister paid a visit to South Korea in March 1999 for the first time since 1996. He and the Korean president were to try to resolve their differences over North Korea.(IHT 19-03-99) Although agreeing on the importance of "engagement" with North Korea, Japan insisted that North Korea had to be the first to "respond constructively" to "concerns and anxieties" aroused by the missile firing of 31 August 1998 (See infra at 292) before Japan could contribute "humanitarian assistance".(IHT 22-03-99) 


\section{Malaysia-Singapore}

Malaysia rejected a request from Singapore to move its immigration and customs checkpoint from the Tanjong Pagar railway station in central Singapore to Woodlands, on the border (see: Lease of territory). Other disputes between the two countries concern, inter alia, the water supply agreements which would expire in 2011 and 2061, the high interest rates for (Malaysian) ringgit deposits offered by Singapore banks, and the mandatory savings plan in Singapore which was freezing the deposits of the many Malaysians working in Singapore.(IHT 05-08-98)

In September 1998 Malaysia introduced new rules with regard to entry to its air space by Singapore military and rescue planes, prescribing case-by-case permission. The previous arrangement of blanket approval of the military aircraft of one state flying at low altitude over another without warning was highly unusual.(IHT 18-09-98)

\section{Malaysia-US}

In a speech on the eve of the annual summit meeting of the APEC forum the US vice-president strongly endorsed efforts of political reformation and strongly assailed the use of authoritarian rule in a time of economic crisis, implicitly though clearly referring to the prevailing political situation in the host state Malaysia. The latter reacted by accusing the US on 17 November of inciting lawlessness in order to overthrow a constitutionally elected government.(IHT 17-11 and 18-11-98)

\section{Myanmar-US}

The US permanent representative to the UN abandoned his plan to visit Myanmar, as the Myanmar government let it be known that he would not be eligible for a visa unless the US ban on Myanmarese government members entering the US were either waived or lifted. A 1996 US executive order barred members of the military government of Myanmar and their families from visiting the US.(IHT 08-04-98)

\section{North Korea-US}

While preparing for four-party talks (see supra at 262) bilateral talks continued and expanded to areas of missile proliferation, food aid and missing US servicemen (see infra at 287)(IHT 02-07-97) It was reported later that the US was approximately doubling its previous donation to North Korea through, inter alia, the UNWFP.(IHT 16-07-97) However, on 27 August 1997 North Korea suspended the talks in view of the defection of their ambassador to Egypt and his brother to the US (see supra at 263).(IHT 28-08-97)

After more than a year, the parties met again in New York in early October 1998 and discussed North Korea's development of long-range missiles and its export of missile technology to countries in sensitive regions.(IHT 02-10-98) The meeting was resumed in March 1999. During these talks agreement was reached on repeated US inspections of a suspected site (see: Nuclear energy matters: New North Korean building activities).(IHT 17-03-99)

In May 1999 the US sent an envoy to North Korea with, reportedly, a proposal gradually to lift the 46-year-old economic embargo in exchange for several major 
concessions, including an agreement that North Korea would end its long-range missile programme. Details of the proposal were not divulged. It would be the biggest change in the US approach to North Korea since the Korean War.(IHT 22/23-05 and 27-05-99)

\section{Pakistan-US}

The US secretary of state visited Pakistan in November 1997, the first to visit Pakistan since 1983. According to US embassy officials in Islamabad cooperation on anti-terrorism would take an important place in the discussions. Besides this, the US would encourage peace efforts in Afghanistan where the Taleban was recognized only by Pakistan, the United Arab Emirates and Saudi Arabia.(JP 17-11-97)

\section{South Korea-Vietnam}

Over a period of about eight years during the Vietnam War South Korea had sent 300,000 troops to fight alongside the US forces.

At a meeting between the president of South Korea and the prime minister of Vietnam on the sidelines of the ASEAN summit of December 1998 at Hanoi the South Korean president for the first time expressed regret over the role of South Korea in the Vietnam War. However, the Vietnamese prime minister said that his country did not expect apologies nor reparations: "If they feel regret for what they did in the past, that's their decision. We want to close the past, look to the future and build better relations with other nations."(IHT 17-12-98)

\section{South Korea-Russia}

The president of South Korea went to Russia in late May 1999, firstly to conduct his summit diplomacy with the powers surrounding his country and secondly, to discuss the problem of the Russian debt.

As to the former, he tried to get support for his "sunshine policy", while Russia on its part put forward its wish to participate in the four-party talks among North and South Korea, China and the US, or, alternatively, to start a new "multiple regional dialogue" including all powers in the area and covering a broader agenda.

With regard to the latter item, Russia reportedly offered to South Korea Russian submarines as payment for the $\$ 1.7$ billion in loans, plus interest, extended from 1990 to 1992.(IHT 24-05-99)

\section{INTERNATIONAL CRIMINAL LAW}

\section{Opposition to the establishment of an International Criminal Court}

China declared on 16 June 1998 its opposition to an international criminal court at the UN conference on establishing such a court because of the Court's jurisdiction to deal with the internal affairs of a country without the latter's consent.(IHT 17-0698) 


\section{INTERNATIONAL ECONOMIC RELATIONS AND TRADE}

\section{US sanctions in trade dispute against Japan: retaliatory port fines (See also: 7 AsYIL 449-450)}

Under the Japanese port system, foreign shipping companies are not themselves allowed to choose who will unload their ships or even to negotiate the price of the job;or are they allowed to establish their own companies to provide port services. Prior approval is required for even minor cargo-handling changes. The ruling body is the Japan Harbour Transportation Association. In September 1997 the US imposed retaliatory fines on US port calls by Japanese ships, on the grounds that Japan had refused to ease costly restrictions on foreign ships operating in Japanese ports. As three Japanese shipping firms had failed to pay the fines, the US imposed a ban on the use of US ports and detained those already in port. Japan was of the opinion that the fines violated the US-Japan Treaty of Friendship, Commerce and Navigation.

In October 1997 Japan agreed to streamline the licencing procedures at its ports and to create an independent agency to monitor the harbour system. Following this agreement the US Federal Maritime Commission decided to postpone enforcement of the access ban, but it later transpired that no agreement had yet been reached on the issue of sanctions.(IHT 17-10 and 18/19-10-97;JP 20-10 and 27-10-97)

\section{US renewal of most-favoured-nation treatment for China}

Citing the Indian and Pakistani nuclear tests as demonstrations of an urgent need to maintain constructive relations with China as part of a strategic relationship, the US decided to grant the annual renewal of the most-favoured-nation status for China.(IHT 24-07-98)

\section{Most-favoured-nation status for Vietnam}

Six countries in the world did not enjoy most-favoured-nation treatment vis-à-vis the US for various reasons: Afghanistan, Cuba, Laos, North Korea, Serbia and Vietnam.

Vietnam was on that list under a 1974 law that denies that treatment to countries with restrictive emigration policies. In March 1998 the US president issued a waiver exempting Vietnam from that law and on 3 June the waiver was renewed for another year.(IHT 24-06-98)

\section{(NON-)INTERVENTION}

\section{US bombing of sites in Afghanistan}

On 7 August 1998 the US embassies in Kenya and Tanzania were bombed, causing a great number of casualties. The bombings were classified as acts of terrorism. It was argued, inter alia, that an attack on a diplomatic mission counts as an attack on the state itself under international law; US officials put high on their list of suspects the name of the Saudi Arabian national OSAMA BIN LADEN who was expelled from Sudan in 1996 under US pressure and had fled to Afghanistan. 
On 20 August 1998 the US delivered surprise missile strikes against sites in Afghanistan (and Sudan) in an effort to destroy key bases used by Muslim groups allegedly involved in the explosions in Nairobi and Dar-es-Salaam. The US president described the attack as a response to terrorism and said, inter alia: "The US launched an attack ... on one of the most active terrorist bases in the world. It is located in Afghanistan and operated by groups affiliated with OSAMA BIN LADEN, a network not sponsored by any state but as dangerous as any we face." He mentioned the following reasons for the action: "convincing evidence [that] these groups played the key role in the embassy bombings", "these groups have executed terrorist attacks against Americans in the past", "compelling information that they were planning additional terrorist attacks against our citizens ..." and that "they are seeking to acquire chemical weapons and other dangerous weapons". The US Defense Secretary described the action as "not just retaliation for a specific act but also an act of selfdefense" by the US to protect American lives around the world. He said that both countries had harbored the planning and training of terrorists and had helped them to launch attacks, thereby making them legitimate targets for US military attacks. The chairman of the joint chiefs of staff said that the operations were directed against "a clear and imminent threat" to the US.(IHT 08/09-08;14-08 and 21-08-98)

Pakistan condemned the attack and filed a protest, inter alia, over the fact that the missiles launched into Afghanistan flew through Pakistan air space without permission.(IHT 22/23-08-98)

\section{Reactions in Southeast Asia on the treatment of former Malaysian deputy prime minister}

Breaking a long-standing tradition in Southeast Asia of non-interference in the internal affairs of other countries, there were criticisms of the detention and alleged bad treatment of the former deputy prime minister of Malaysia.

In view of the coming APEC meeting in November 1998 in Malaysia, the Philippine president said he was considering not to attend "because they put my good friend behind bars". Criticism was also expressed by Thai officials, and from the Indonesian side (IHT 02-10-98), to the extent that the Indonesian president canceled a planned visit although care was taken not to link this with the events in Malaysia.(IHT 07-10-98)

\section{Asian reactions to NATO attack on Serbia}

Among the Chinese reactions to the attack which began on 24 March 1999 were those contained in the official newspaper People's Daily which called the operation a "dangerous precedent of naked aggression". Noting that ethnic conflict in Yugoslavia had ancient roots, it blamed the recent violence in Kosovo on "illegal Albanian armed forces. ... There are many countries with problems involving ethnic minorities. ... If we encourage division, won't the world fall into chaos? ... NATO's use of military force ... is without reason or legal basis ...". It considered the action as part of a dark new "strategy for global intervention". China held the view that the operation required approval by the UN Security Council. A month or more later some 
change was said to be visible in the Chinese attitude when certain of its top leaders said that China opposed massacres and the expulsion of people from their homes.

Indonesia, Vietnam, Thailand, and Iran also spoke out against the NATO action; the Philippines indicated it would not take sides, while Japan and Singapore supported the action.

The Japanese foreign minister said that "Japan understands NATO's use of force as measures that had to be taken to prevent a humanitarian catastrophe or a further increase in victims" and the Japanese prime minister called the air strikes "an unavoidable step to prevent a humanitarian atrocity".(IHT 26-03, 8/9-05-99) There was a contrast between the reactions of Indonesia and Malaysia: Malaysia was seen to give some support to the attacks as their being necessary to prevent the "genocide" of the Kosovar Albanians. After criticizing US strikes in Iraq, Sudan, and Afghanistan, its backing of the attacks in Kosovo was described by the Malaysian representative to the UN as a "reluctant exception" to the idea that all international security issues must be channeled through the UN Security Council.(IHT 14-04-99)

\section{JAPAN'S MILITARY ROLE}

See: Territorial sovereignty

\section{JOINT DEVELOPMENT AND JOINT VENTURES}

See also: Oil and Gas: Division and sharing of Caspian oil; Territorial claims and disputes: Spratly Islands

\section{Russian plans for disputed islands}

In talks between the Russian and Japanese foreign ministers the Russian side was reported by a Japanese spokesman to have offered to his Japanese colleague plans for the joint development of the islands off the Japanese island of Hokkaido which are under dispute between Russia and Japan.

There was, besides, a proposal to set up a Japanese representative office in Yuzhno-Sakhalinsk, the main city on the Russian island of Sakhalin.

The two sides also agreed to prevent recurrences of incidents like a week before when Russian vessels fired warning shots at Japanese fishing boats in Russian waters near the disputed islands.

Referring to the rapprochement achieved on the G-8 meeting in Denver, USA, two weeks earlier, the Russian minister mentioned the wish of huge Japanese investments in Sakhalin and on the Kuril Islands.(IHT 01-07-97) 


\section{JUDICIAL ASSISTANCE}

\section{Detention of criminal suspect by Pakistan}

A suspect in the bombing of the US embassies in Kenya and Tanzania was arrested in Pakistan and handed over to the authorities in Kenya. The person was arrested soon after his arrival at Karachi on 7 August 1998, the day of the bombings. There were conflicting reports as to whether or not officials of the US CIA who had come to Pakistan had had access to the man and had accompanied him to Nairobi.(IHT 17-08-98)

\section{JURISDICTION}

\section{Extraterritorial scope of municipal legislation}

(See: Sanctions)

Iran sentenced in foreign court for acts outside Iran and outside the state of the forum

A US court granted punitive damages to the US victim of a bombing in Gaza in 1995. The Court held that the bombing was carried out by the "Islamic Jihad" and that this grouping was financed by the Iranian government, making Iran liable for the bombing.

The ruling was the first case of a US court holding a foreign state liable for sponsoring "terrorism". It was based on a new US law allowing US citizens to file suit in US courts against foreign states for tort if these states are classified by the State Department as sponsors of terrorism.(IHT 12-03-98)

In late August 1998 there were reports of another federal court decision ordering the government of Iran to pay civil damages for its role in the kidnapping of three Americans who were held hostage in Lebanon by Islamic groupings during the late 1980s. The Iranian government did not take part in the court proceedings.(IHT 29/3008-98)

\section{KOREAN WAR}

\section{Exhumation of remains of US soldiers}

Under an agreement reached in May 1997 North Korea announced that these exhumations would start by way of joint effort with the US in July. There were 8,100 US troops still listed as missing in the Korean War.(IHT 01-07-97)

\section{LAW OF ARMED CONFLICT}

\section{US bombing of Chinese embassy at Belgrade}

NATO warplanes had bombed and destroyed the Chinese embassy building in Belgrade on 7 May 1999, allegedly in the mistaken belief it was a military target, causing at least three deaths and twenty wounded. The US Central Intelligence 
Agency and the US Defense Department issued a joint statement, blaming faulty intelligence for the error: "... The bombing was an error. Those involved in targeting mistakenly believed that the [Yugoslav] Federal Directorate of Supply and Procurement was at the location that was hit. ... Clearly, faulty information led to a mistake in the initial targeting of this facility. ..." Later, the US Defense Secretary attributed the bombing to "institutional error" [in contradistinction to human error] and reliance on old, insufficiently updated maps and educated guesses rather than on first-hand information. The US and NATO leaders expressed regret and apologized for the bombing.

The Chinese government protested furiously and called an emergency session of the UN Security Council. Officials expressed scepticism that the US air force, with the most modern technology at its disposal, could have hit a large, well-identified embassy building in error. In China tens of thousands of protesters surrounded the US embassy in Beijing and diplomatic facilities in other cities.(IHT 10-05 and 12-0599)

The first concrete Chinese response consisted of the announcement that China was suspending its cooperation with the US on stopping the proliferation of weapons of mass destruction. China also suspended its dialogue on human rights and high-level contacts with the US, exacerbating the already extant downward trend in relations with the US. The foreign minister presented the Chinese demands, consisting of an "open and full apology", an investigation, publication of its results, and US action "severely (to) punish those responsible". The US president expressed his "sincere condolences" in a telephone conversation with his Chinese colleague on 14 May 1999. In mid-June a high-level US delegation presented a detailed reconstruction of the events that led to the bombing, but China rejected the excuses offered.(IHT 11-05;15/ 16-05;17-06 and 18-06-99) China later declined to resume negotiations with the US on its entry into the WTO until it received a "full and satisfactory explanation" of the bombing.(IHT 30-06-99)

In late June press reports said that according to "American officials and a Western diplomat" there was in fact an intelligence-gathering nerve centre in the embassy building and two of the three Chinese persons killed were not journalists but intelligence officers.(IHT 26/27-06-99)

\section{LEASE OF TERRITORY}

\section{Lease of Singapore territory for Malaysian railways}

(See also: Inter-state relations: Malaysia-Singapore)

Tanjong Pagar railway station in central Singapore, property of the Malaysian railways, is located on land that is part of a parcel of 200 hectares leased by Malaysia under a 999-year lease and that includes a 40-kilometre corridor of Singapore territory to the border with Malaysia. The lease was established during the period of British rule.

Malaysia rejected a Singaporean request to move its immigration and customs checkpoint from the railway station to the border. The issue centred on the issue that 
Malaysia might have to surrender the land if there were no longer a checkpoint.(IHT 05-08;06-10-98)

\section{MERCENARIES}

\section{Gurkha soldiers in British service}

Retired Gurkha soldiers demanded pensions equal to those of their British counterparts. They rejected an offer from the British government of an increase from twentythree to fifty-one per cent for the 26,375 individuals in question.

At the time of report 3,000 Gurkhas were still on active British duty.(IHT 17-0798)

\section{MIDDLE EAST ISSUES}

See: Inter-state relations: Asian attitudes, etc.

\section{MIGRANT WORKERS}

\section{Malaysia}

Malaysia said it expected to deport a million foreign workers in 1998 following the reduction of the work force in some sectors of industry due to the economic slowdown.

Malaysia had about two million legal foreign workers, or one-fifth of the work force, many of whom hailed from Indonesia. Besides, workers from Bangladesh, Thailand and India come to Malaysia in search of work.

Next to the legal workers there were about 800,000 illegal foreign workers.(IHT 03/04-01-98). Malaysia said in June it expected to deport 200,000 illegal Indonesian immigrants by mid-August 1998.(IHT 25-06-98)

\section{Thailand}

The government announced on 19 January 1998 that it planned to deport 300,000 foreign workers over the next six months by not renewing their work permits. Besides this, it was the government's intention to repatriate a further one million illegal immigrants (most of them from Myanmar). All this was part of a programme to ease the impact of the economic crisis.(IHT 20-01-98)

\section{Indonesian workers abroad}

It was reported that up to October 1997 more than 900,000 Indonesians had gone abroad as migrant workers, mostly in Malaysia, Saudi Arabia, Singapore and Hongkong.(Kompas 16-11-97) Half a million were in Saudi Arabia, forming 25 per cent of expatriates working there.(JP 09-10-97)

The Saudi authorities had detained 1,000 Indonesians for either overstaying their visas or lacking the documents to stay there. The government aimed at deporting 
more than 100,000 illegal workers. In October 1997 the Indonesian government decided to repatriate about 5,000 (reference was later made to 9,000) illegal Indonesian workers stranded in Saudi Arabia, but in November 1997 Indonesia had airlifted almost 22,000 of its illegal workers from Saudi Arabia.(JP 10-11-97)

\section{MILITARY ALLIANCES}

\section{Japan-US}

The two countries reached a military agreement, spelling out the Japanese support for the US in the event of war in Asia. The agreement was contained in the so-called Defence Guidelines, which constituted an update of the former arrangements designed for the Cold War period. The agreement was silent on a possible conflict relating to Taiwan. It did not specify the territorial scope of the agreement. An interim report on the defence pact was made public on 8 June 1997.(IHT 31-07-97)

The Guidelines were announced on 23 September 1997. Under the agreement Japan would, for the first time since the Second World War, engage in military activities outside its borders in military conflicts involving the US. Japan would provide minesweepers and conduct search and rescue missions in international waters; use its navy to conduct inspections of ships at sea to enforce UN-sanctioned embargoes, and assist with communications and surveillance in international waters and airspace. It would allow its civilian airports, ports and hospitals to be used by US troops; it would accept refugees from war zones and receive non-combatants evacuated from areas of conflict. The Guidelines call for Japanese support for US forces in conflicts in "areas surrounding Japan" without further specification. However, as required by the Japanese constitution, no Japanese forces would be required to fight or even enter areas of combat. Japan's logistical support for US troops (there are 47,000 US troops stationed in Japan) specifically excludes providing them with weapons or ammunition.(IHT 24-09-97)

The Japanese Lower and Upper Houses of Parliament on 27 April 1999 and 24 May 1999 passed the legislation necessary for the implementation of the above agreement.(IHT 28-04 and 25-05-99)

\section{US bases on Okinawa}

(See also: 7 AsYIL 457)

The governor of Okinawa on 6 February 1998 announced that Okinawa had decided not to accept the plans for a new US military heliport, thus effectively denying the intended closure of the Futenma air station.(IHT 07/08-02-98)

\section{MILITARY COOPERATION}

\section{India-Russia}

The two countries agreed to extend until 2010 a 1994 agreement on military and technical cooperation that was originally due to expire in 2000.(IHT 13-10-97) 


\section{China-US}

China and the US on 12 December 1997 initialled an agreement aimed at preventing naval clashes and accidents at sea, the "Maritime Military Consultative Agreement".(JP 14-12-97)

\section{Philippines-US}

The Philippines and the US signed an agreement on military cooperation on 10 February 1998. It dealt, inter alia, with the "status of visiting forces". The "Visiting Forces Agreement" enabled the two parties to resume major military exercises, and is similar to those concluded by the US with Japan, South Korea and other countries.(IHT 15-01 and 11-02-98) The Philippine president said that a continuing conflict with China over ownership of part of the Spratly Islands closest to the Philippines underlined the need for such an agreement. The agreement proved controversial because of sensitivity about issues of national sovereignty and jurisdiction. The Supreme Court in June 1999 ordered the government to answer questions regarding its constitutionality raised by opponents of the pact.(IHT 04-08-98 and 10-06-99)

\section{Singapore-South Africa}

Singapore reached an agreement with South Africa allowing its troops to hold exercises in South Africa. Singapore has overseas training arrangements with various Asian countries as well as with Australia and the US.(JP 12-11-97)

\section{Five-Power Defence Arrangement}

Malaysia had withdrawn from the annual military exercise for 1998 of the FPDA, officially for economic reasons. The FPDA is a cooperation agreement between Malaysia, Singapore, Britain, Australia and New Zealand for regular exercises between the naval and air forces of the member states such that they can operate effectively together in a crisis situation. The agreement includes an integrated air defence for Malaysia and Singapore.(IHT 22-09-98)

\section{Cooperation agreements of Southeast Asian countries with the US}

Instead of seeking bases under US military control such as those in Japan and South Korea it was said that the US aimed at new agreements with Southeast Asian countries increasing US access to local bases and support services, in return for the training and supply of local forces. These were so-called Acquisition and CrossServicing Agreements.(IHT 03-12-98)

\section{MISSILE TECHNOLOGY}

\section{North Korean missile development, deployment, exports}

In September 1997 it was reported that a US military satellite had detected North Korean deployment of a ballistic missile, allegedly of the "Rodong 1" type capable of reaching Tokyo. Earlier experiments with Rodong 1 missiles had been conducted 
in 1991 and 1993.(IHT 23-09-97) In August 1998 it was reported that a longer-range missile, named "Taepo-Dong-1" by US intelligence analysts, was test-fired into waters off northern Japan. The second stage of the missile, containing the cone, flew over Japan and landed in the Pacific Ocean. These reports about the firing were at odds with a North Korean explanation that it in fact launched not a missile but a broadcast satellite. The US retreated from their initial assessment and admitted being unsure of the true nature of the launch. Russian sources said that Russian space tracking devices had confirmed the North Korean statement. Finally, the US maintained that North Korea tried but failed to launch a small satellite and that the rocket in question was much stronger than originally reported.(IHT 01-09;04-09;5/6-09;07-09 and 16-0998)

On 16 June 1998 North Korea declared that it would continue to develop, test and export ballistic missiles. Addressing itself to the US it said: "If the US really wants to prevent our missile export, it should lift the economic embargo as early as possible and make a compensation for the losses to be caused by discontinued missile export. ... Our missile export is aimed at obtaining foreign money, which we need at present."(IHT 17-06-98)

There were reports according to which North Korea proposed a compensation of $\$ 1$ billion per year for three years. In late March 1999 the US again warned North Korea of "very serious negative consequences" for the evolution of mutual relations if it were to test-fire or export its long-range missiles. On the other hand it was said on behalf of the North Korean foreign ministry that it was North Korea's "legitimate right to self-defence to develop, test and produce missiles by its own efforts to defend the security of the country because the US [was] posing constant threats" coming from "enormous nuclear missiles and weapons of mass-destruction."(IHT 01-04-99)

\section{Iran}

(See also: Embargo)

According to US reports of 15 December 1997 satellite reconnaissance had discovered tests for Iranian ballistic missiles (the "Shahab 3") capable of carrying a one-metric-ton warhead further than 800 miles (intermediate range). [A US law banned any foreign company from supplying Iran with certain prohibited missile components from aerospace contracts in the US.](IHT 16-12-9 and 10-03-98) The actual testing of the missile was confirmed by Iran in late July 1998. It was suspected that North Korean assistance was involved.(IHT 24-07 and 28-07-98) Iran denied any current foreign contribution to its missile technology as it had reached technological self-sufficiency. On the other hand US sources said that Iran was recruiting Russian scientists to work in Iran.(IHT 11-12 and 12/13-12-98)

\section{Pakistan}

Pakistan successfully tested a medium-range missile ("Ghauri") with a range of approximately 900 miles (1,500 kilometres), believed to be capable of carrying a nuclear warhead.(IHT 07-04-98) The realization of the missile was considered by the US to be based on purchases from North Korea in a 1997 deal.(IHT 15-05-98) 
The US tried to prevent the testing by offering "to help resolving" an eight-year old dispute over $\$ 650$ million that Pakistan had paid for an order of fighter planes which had never been delivered by the US (see 1 AsYIL 271; 2 AsYIL 286; 4 AsYIL 508; 5 AsYIL 486 and 6 AsYIL 449).(IHT 13-04-98)

Three days after India launched a nuclear-capable missile (infra) Pakistan responded by first firing off a new and improved version of its own ballistic missile, the Ghauri-2, which flew about 1,120 kilometres, and subsequently another, the "Shaheen-1", with a range of 725 kilometres. However, India emphasized there was no violation of the Lahore Declaration (supra at 277).(IHT 15-04 and 16-04-99)

\section{India}

India successfully completed a series of test firings on 16 November 1998 of the naval version of its "Trishul" missile.(IHT 17-11-98)

US sources reported that India was developing a sea-launched ballistic missile with Russian help. The missile was said to be named "Sagarika" and to have a range of 325 kilometres. The Indian Defence Ministry denied the existence of the project.(IHT 28-04-98)

It was announced on 11 April 1999 that India had test-fired a missile, the "Agni2 ", with a range of 2,400 kilometres that was capable of delivering a nuclear warhead.(IHT 13-04-99)

\section{China}

According to US intelligence reports China was close to deploying an intercontinental ballistic missile with a nuclear warhead, the "Dong Feng-31", designed on the basis of US technology acquired through espionage; however, this was contrary to the position taken by the US government, according to which there was no evidence that Chinese nuclear weapons relied on US secrets.(IHT 15/16-05-99)

\section{MONETARY AND FINANCIAL MATTERS}

\section{Asian central bank co-operation}

A joint statement of 25 July 1997 by central bankers from eleven Asia-Pacific countries at a regular meeting of the Executives' Meeting of East Asian and Pacific Central Banks at Shanghai pledged to expand cooperation but fell short of commitments to intervene directly to prop up neighbouring currencies. The statement was aimed at curbing speculation in Asian currencies by making it more expensive for investors to bet against them, but the group failed to introduce any specific measures.(IHT 26/27-07-97)

\section{Swap agreement among Southeast Asian central banks}

The central banks of Thailand, Malaysia, Indonesia, Singapore, and the Philippines agreed to renew for one year a swap agreement to help to prop up their currencies. The accord allows member states to exchange their respective local currencies for dollars when needed.(IHT 26/27-07-97) 


\section{Abortive "ASIAN Fund"}

ASEAN member states took the occasion of the annual IMF/World Bank meeting in late September 1997 to push for a regional economic stability fund intended to bail out economies in emergency situations.

The participation of Japan and China in such project was considered essential. So far regional cooperation during the financial crisis consisted only of bilateral repurchase agreements between central banks.(IHT 20/21-09-97)

Despite Western reservations, the idea of an "Asian Facility" initially won the backing of Japan and Hong Kong.(IHT 23-09-97) Among other advantages, the "fund" would be able to draw on standby credits from regional members of up to $\$ 100$ billion. US objections were reportedly based firstly, on fears that such a fund might undercut the tough conditions attached by the IMF to bail-outs, or, in other words, would remove incentives for the Asian countries concerned to modernize their economies in order to fulfil the stringent lending conditions of the IMF; and secondly, on concerns that a Japanese-led regional organization might exclude the US.(IHT 03-10-97) In November 1997 Japan modified its position following the concerns voiced by the US, the IMF and others.(IHT 14-11-97) The hope that specifics of the fund would be completed at an Asia-Pacific finance ministers' meeting (ASEAN countries and Australia, China, Hong Kong, Japan, South Korea, and the US) in Kuala Lumpur in early December was not fulfilled and the matter was postponed.(IHT 0511; 01-12-97;JP 03-12-97)

Instead, agreement was reached at a meeting at Manila on 19 November 1997 to work towards setting up a financial facility. The facility would be strongly tied to IMF assistance and any current situation would dictate which countries became contributors. The group of countries should meet regularly to monitor the region's economies to "help identify potential risks to growth and financial stability and advise on appropriate policy responses to reduce those risks". On its part the US announced that it would participate on a "case-by-case basis". Thus the agreement avoided any reference to earlier proposals about a special regional fund. The new assistance facility was to be designed at a meeting in Japan in 1998.(IHT 20-11 and 24-11-97)

At the ASEAN-plus-Three summit meeting at Kuala Lumpur in mid-December 1997 it became clear that Japan and China were not willing or able to lead the way out of the prevailing regional financial crisis, stressing that their assistance to the region would come within the IMF framework, and ASEAN consequently called for "greater ... international efforts, including by the major economies such as the European Union, Japan and the US and international institutions, to overcome this situation ...".(IHT 16-12-97;JP 17-12-97)

\section{World Financial Organization}

The UN Economic and Social Commission for Asia and the Pacific (ESCAP) laid out a blueprint for a new global body to regulate short-term capital flows. The organization would have a "specific mandate dealing with the monitoring of all shortterm cross-border flows". The idea was launched in the UN Economic Survey of Asia and the Pacific 1999.(IHT 09-04-99) 


\section{Japanese guarantee of Asian government bonds}

In addition to a $\$ 30$ billion loan package for Asia announced in 1998, Japan announced a new commitment to guarantee government bonds in an amount of $\$ 17$ billion. The commitment was made on 15 May 1999 during a meeting of finance ministers of the APEC countries in Malaysia.(IHT 17-05-99)

\section{NUCLEAR ENERGY MATTERS}

(See also: Embargo)

\section{Implementation of KEDO agreement}

August 1997 marked the formal beginning, after lengthy delays, of the construction in North Korea of the nuclear plants stipulated in the 1994 Agreed Framework between North Korea and the US.(IHT 19-08, 20-08-97) (see 5 AsYIL 471;545; 6 AsYIL 435; 7 AsYIL 465) The first of the two nuclear plants was to be built near Sinpo. The reactors were to be delivered by the US nuclear equipment producer Combustion Engineering (see the DPRK - KEDO agreement of 15 December 1995, Art.1 para.1, where the reactor model is defined as being "the advanced version of US-origin design and technology currently under production") thought to be "of the Korean standard nuclear plant model" (see the Agreement establishing KEDO, Art.II(a)(1), allegedly to meet South Korean sensitivities because of its assigned obligation to pay) .

Under the Agreed Framework the frozen nuclear facilities would be dismantled when the light water project is completed. This completion would, however, need the necessary infrastructure to handle the electrical output, and the existing North Korean transmission and distribution system appeared unable to do this. There seemed to be disagreement regarding where responsibility lay for providing the necessary upgrade. If the North Korean potential nuclear weapons programme were to remain frozen, the US would have to take responsibility for assured funding of the KEDO activities. On the other hand, until North Korea brought itself into full compliance with IAEA safeguards, it was to be expected that critical components necessary for the light water reactor to start operating would not be delivered.(IHT 19-08-97)

In early February 1998 it was reported that South Korea had told the US that the Asian financial crisis had disabled it from paying its promised share towards the construction of the power plants. The possibility of the US's taking over the cost for the early stages of the project was negligible since the US Congress had refused to participate in the direct funding of the reactor construction. It was reported that under an informal agreement South Korea would pay 70 per cent ( $\$ 3.5$ billion) and Japan 20 per cent ( $\$ 1$ billion). In early June Japan confirmed that it would contribute around \$1 billion (but parliamentary approval was not granted until early May 1999). Instead, the US was supposed to finance the fuel oil deliveries to North Korea to supplement its energy supplies pending the completion of the promised light-water reactors ( $\$ 35$ million a year).(IHT 06-02;14-05;09-06-98 and 05-05-99) There were, however, also problems with US Congress approval of funding for the oil deliveries, 
necessitating financing by borrowing and thus causing delays.(IHT 02/03-0598)[According to later US press comments the US had struck the 1994 deal as it assumed that the beleaguered North Korean government would not continue long enough to benefit from the most ambitious features of the accord, and that US policymakers nursed private hopes that the US would never have to deliver on the expensive and controversial reactor scheme.(IHT 01-04-99)]

In late April 1998 the then US Secretary of State held talks with her South Korean colleague on the implementation of the 1994 agreement. This implementation was said to be at great risk because no agreement could yet be reached on the financial consequences of providing North Korea with the promised replacement energy in the form of oil. It was reported that on the one hand the US sought to build a sense of urgency on the subject, but on the other hand made clear that it would find a way to honour its commitments. The Secretary of State was quoted as saying: "There should be no doubt we will fulfil an agreement as important as this one."(IHT 02/0305-98) Early July 1998 the lack of funds still existed, causing the US Secretary of State remark that it would be a "disaster if we let this fall apart".(IHT 08-07-98) Generally speaking it could be said that the US had not lifted sanctions on North Korea despite the 1994 agreement. Also, Japan became even more reluctant to sign a formal funding agreement as a result of its dismay of the alleged launching of a new North Korean missile in August 1998 (see supra at 292)

North Korea had started complaining that the US was not living up to the terms of the agreement.(IHT 07/08-03-98) On 8 May 1998 such complaints were accompanied by the announcement that it might restart the North Korean nuclear programme by unsealing a nuclear reactor in Yong Byon that under the agreement was to have been closed permanently, to "conduct maintenance". It was also divulged that technicians were barred from packing the last of the reactor's fuel rods for shipment out of the country. It was reported, however, that such a reopening of the Yong Byon plant was primarily a symbolic act without immediate effect, since the approximately 200 spare fuel rods (out of the original 8,000) contained too little plutonium to pose a nuclear threat. American and Asian experts also said that it would be too expensive and technologically complex for North Korea to reopen the plant.(IHT 14/ 15-05-98)

The reports of a new underground complex near Yong Byon (see infra) made the US Congress, never enthusiastic about the 1994 agreement, even less likely to agree on financing the promised fuel oil deliveries which could, in turn, give North Korea an excuse to abandon the 1994 nuclear agreement.(IHT 17-08-98) In early October the US president even diverted an amount from the US foreign aid budget to be able to comply with the US obligation to deliver oil to North Korea for the year 1998. However, even then there would be a shortfall of 134,000 tons for which no additional funds were available. (IHT 05-10-98) Later the Congress approved the budget for the oil purchase though linked to the condition that the president certify that the recently discovered underground facility (see infra) was not used to build nuclear warheads and that progress was being made in dissuading North Korea from building missiles for nuclear warheads, referring to the recent firing on 31 August (see supra at 292).(IHT 21-10-98) Meanwhile, the firing of a long-range missile in 
late August 1998 caused Japan to suspend financial assistance for the building of the reactors, break off talks aimed at restoring diplomatic relations, end food aid and ban flights between Japan and North Korea.(IHT 04-09-98)

\section{New North Korean building activities}

In August 1998 US intelligence agencies said spy satellites had detected a secret underground complex in Kumchangri, 25 miles from Yong Byon in North Korea that they, according to newspaper reports, "believe is the centerpiece of an effort to revive" the frozen nuclear weapons programme. However, there was no evidence yet of a start of building a new reactor or a reprocessing plant. Intelligence estimates of how long it would take to complete the project ranged from two to six years, depending in part on how much outside help would be received.(IHT 17-08-98)

Upon US insistence that it be given access to the complex for inspection, North Korea attached the condition of payment of $\$ 300$ million for such access by way of "compensation for the insult" of the US's suggestion that North Korea was violating the 1994 agreement.(IHT 20-11-98) However, in late December 1998 it was reported that the demand for payment had been dropped and replaced by a demand for more food aid.(IHT 16-12 and 28-12-98) Later US news reports referred to several, or even a dozen, underground complexes "around the country" and the need to have regular inspections instead of a single access.(IHT 04-01-99) In March 1999 agreement was reached on repeated, at least two annual, inspections of the suspected site. Though North Korea initially insisted on a specific US commitment on food aid in return, this demand was later dropped.(IHT 17/18-03-99) It was later agreed that US experts visit the site on 20 May 1999.(IHT 12-05-99) The investigation of the site took place until 24 May. The 14-member team was allowed unhindered access, but the only find was an unfinished site with vast, empty, tunnels. The US State Department said that the inspection yielded no evidence that North Korea was in violation of the 1994 agreement, and that the tunnel complex "was at a stage of construction prior to the time when any relevant equipment other than construction equipment would be expected to be present".(IHT 28/29-05 and 30-05-99)

\section{Chinese restrictions of exports of nuclear weapons and technology, and the US sale of nuclear technology to China}

New Chinese rules were issued on 11 September 1997, enabling the government to bar the transfer of the relevant materials and technology with dual civilian and military uses to countries opposing international safeguards. The regulations were intended to meet US demands in order to end a ban on the building of nuclear power plants in China by US companies.(IHT 12-09-97) This was accompanied by some assurance of non-proliferation of nuclear weapon technology.

The new restrictive Chinese rules were also necessary for a US ban on sales of nuclear technology to China to be lifted, in the sense that US presidential certification that China was no longer helping other states in developing nuclear weapons was required in order that a 1985 bilateral agreement on peaceful nuclear cooperation, allowing US companies to sell nuclear reactors to China could come into effect.(IHT 20-10-97) That certification was finally announced during the visit by the Chinese 
president to the US in late October 1997 and issued in a statement to the US Congress in December 1997. The documents for the re-activation of the 1985 agreement were signed by the US president on 12 January 1998.(IHT 30-10;12-12-97 and 17/18-01-98) This was followed by the issuance of implementation measures to the above Chinese regulations on 17 June 1998.(IHT 18-06-98)[The embargo on transfer of nuclear technology was based on the US 1978 Nuclear Non-proliferation Act, which also applied to other states such as India.]

\section{Russian and South African sale of atom plants to China}

South Africa sold the last of its sensitive nuclear-fuels equipment to China, just weeks ahead of the planned transfer of diplomatic recognition from Taipei to Beijing.(JP 15-12-97)

Russia and China in late December 1997 signed an agreement for the building of a nuclear power plant consisting of two light water reactors at Lianyungang in eastern China. The contract was the result of a 1992 nuclear cooperation agreement.(IHT 30-12-97)

\section{Indian and Pakistani nuclear weapon tests}

India conducted three underground nuclear tests (with a fission device, a low-yield device and a thermonuclear (hydrogen) device respectively; however, the number of tests was later considered exaggerated by outside experts) on 11 May 1998, the first since 1974, and a month after Pakistan tested a new ballistic missile (see: Missile technology, supra at 292). Two days later, on 13 May, two more underground tests were conducted.

Previously, India had maintained that its nuclear programme was for peaceful purposes and that it only kept open the nuclear weapons option to ensure national security.

[Neither India nor Pakistan had signed the Comprehensive Test Ban Treaty, nor had the US not ratified it.]

The Indian president wrote a letter to the US president in which he explained the rationale for the tests. In it he said, inter alia: “... We have an overt nuclear weapon state on our borders, a state which committed armed aggression against India in 1962. Although our relations with that country have improved in the last decade or so, an atmosphere of distrust persists mainly due to the unresolved border problem. To add to the distrust that country has materially helped another neighbour of ours to become a covert nuclear weapons state. At the hands of this bitter neighbour we have suffered three aggressions in the last 50 years. And for the last ten years we have been the victim of unremitting terrorism and militancy sponsored by it in several parts of our country, specially Punjab and Jammu and Kashmir..." The contents of the letter were later strongly criticized by others and apparently also regretted by the Indian side.

The tests raised protests from various countries. Among the Asian states there were Japan, Pakistan, and China. Some countries announced the imposition of sanctions. Japan suspended some financial aid and contemplated expanded cuts. The US would cut off some financial aid, prohibit US bank loans to the Indian government 
and restrict exports of "dual-use" equipment. It would also vote against India in the World Bank and the IMF. In late June, however, the World Bank resumed its lending program with the endorsement of the US, as being chiefly of humanitarian character, and thus falling under an exception in the US 1994 Nuclear Non-proliferation Act.(IHT 12-05;13/14-05;01-06;27/28-06 and 17-09-98)

[The Nuclear Non-proliferation Act requires the US government to cut off virtually all direct aid to states that conduct nuclear tests; it also bans American banks from making loans to the governments of those states and mandates that the US vote against aid to those states by the World Bank and the IMF. The law exempts aid for "basic human needs". In September 1998 the US Congress gave flexibility to the President by allowing a one-year waiver of sanctions on India and Pakistan.]

On 21 May 1998 India announced a moratorium on nuclear tests and restated a willingness to negotiate a comprehensive test ban.(IHT 22-05-98)

In a later newspaper interview the Indian prime minister said that India did not intend to build a large nuclear arsenal or create the elaborate command and control systems that other nuclear powers use to manage their weapons. He emphasized that the Indian approach was to have a credible deterrent which should prevent the use of nuclear weapons, and that India carried out the tests in part to prod the five established nuclear weapon states into agreeing to plans to disarm.(IHT 18-06-98)

Despite intense diplomatic pressure not to follow the Indian example, particularly despite a letter from the president of China obviously written at the request of the US president, Pakistan conducted five underground nuclear tests on 28 May 1998 (here too doubt was later cast on the number of tests, considered exaggerated by outside analysts). There was no accompanying "no first use" pledge.

As a consequence of the tests the US and Germany announced sanctions. The US sanctions would be the same as those against India (see supra).

[The US had already ended all military aid to Pakistan in 1990 after the Soviet withdrawal from Afghanistan and the end of Pakistan's role in that war. Under a 1985 US law requiring the president to certify that Pakistan was not building nuclear weapons and thus eligible for continued military and economic aid, that certification was withheld in 1990, thereby cutting off military aid. See the non-delivery of jet fighter planes ordered and paid for, 2 AsYIL 371; 3 AsYIL 442; 4 AsYIL 508; 5 AsYIL 486; 6 AsYIL 448.]

Among the Asian states Japan ordered sanctions, and China expressed "deep regret" about the tests, calling on all South Asian countries "to exercise the utmost restraint and to immediately abandon all nuclear weapons development programs".(IHT 29-05;30/31-5;02-06 and 17-09-98) On 11 June the Group of Seven industrialized states together with Russia decided to deny non-humanitarian loans to India and Pakistan.(IHT 13/14-06-98) However, under pressure from farmers the US government tended to re-allow the sale of wheat to India and Pakistan soon afterwards.(IHT 16-06-98) In early November 1998 the US president decided to lift most of the economic sanctions imposed on India and Pakistan. Left in place were bans on military equipment sales, restrictions on the export of US-made "dual-use" items and US objection, amounting to a veto, to development-project lending to India by the World Bank and other international institutions.(IHT 09-11-98) 
On 11 June Pakistan also announced a moratorium on further nuclear tests, calling it a "confidence-building measure at the regional level".(IHT 12-06-98)

Both India and Pakistan offered lengthy explanations to the IAEA as to why they had proceeded with the tests. (IHT 09-11-98)

\section{Russian construction of nuclear reactors for India}

Russia decided on 22 June 1998 to revive a ten-year-old agreement on the construction of two 1,000-megawatt nuclear reactors in Kudankulam, Southern India, with an estimated worth of $\$ 3$ billion. The agreement had been on hold since the collapse of the Soviet Union. The facility would be subject to safeguards by the IAEA.(IHT 23-06-98)

\section{Russia-Iran nuclear cooperation}

Russia offered to curtail nuclear cooperation with Iran if the US ended its sanctions against two leading Russian nuclear research centres. US fears concerned an eventual Russian delivery of heavy water and graphite reactors in particular. These fears had already led to sanctions against the research centres. The proposal would not interfere with the Iran-Russian scheme to build nuclear reactors at Bushere.(IHT 18-03-99)

\section{OIL AND GAS}

See also: Inter-state relations: China-Russia; Sanctions

\section{Iran and Central Asia}

(See also: Inter-state relations: Iran-US)

It was reported in October 1997 that Turkmenistan planned to open a pipeline that would carry two billion cubic metres of natural gas a year to power plants and refineries in northern Iran. On 29 December 1997 the 125-mile pipeline from the Caspian Sea basin to the northeast Iranian town of Kurd Kui was opened. Until 1993 the gas was exported to Europe exclusively through pipelines that traversed Russia.(IHT 01-01-98) Iran would also begin providing natural gas to Turkish power plants beginning 1998.

Furthermore, Kazakhstan was daily shipping oil from its Caspian Sea port to ports in northern Iran.(IHT 13-10-97)

Despite its non-objection against a pipeline through Iran in July 1997 (see supra at 279), the US later in the year sought to persuade Caspian Sea states to scrap plans for oil and gas pipelines through Iran in favour of a more costly "Eurasian transportation corridor" to the West. The corridor would involve a system of pipelines westward across the Caspian Sea to Baku, and then on to Georgia. From there the pipeline would cross Turkey to the Mediterranean port of Ceyhan. Although the real choice depended on a decision from the oil companies, leaders of the region (Azerbaijan, Georgia, Turkey, Kazakhstan, and Uzbekistan) on 29 October 1998 "strongly confirmed their determination" to realize the American-backed pipeline route, increasing political pressure on the companies.(IHT 21-11-97;30-10 and 09-11-98) 


\section{Kazakhstan oil contracts}

Seven oil companies signed an oil-exploration accord with Kazakhstan, among which were Total, British Petroleum, Agip, Royal Dutch/Shell, BG (UK), Statoil (Norway) and Mobil. The accord covers a 6,000-square-kilometre tract in the northern Caspian Sea. A consortium was also formed by ENI (Agip's parent company) and BG, together with Texaco and AO Lukoil Holding, to develop the Karachaganak fields.(IHT 20-11-97)

On 24 September Kazakhstan granted a controlling interest in its second-largest oil field to the Chinese National Petroleum Company for the amount of $\$ 4.4$ billion. China promised a 1,800-mile oil pipeline to China and one to refineries in northern Iran, which conflicts with US policy. (See supra at 300)(IHT 27/28-12-97)

\section{Chinese oil contracts}

Apart from the above contract with Kazakhstan, China formed a joint venture with the Iranian NIOC to explore offshore in Iran, China and other countries and to upgrade Chinese refineries for purposes of processing more Iranian oil.

It also concluded a $\$ 1.2$ billion agreement in September 1997 with Iraq to develop the Ahdab field when the UN sanctions would be lifted. In 1996 China replaced the (US) Occidental Petroleum Corp. in a $\$ 1$ billion oil and pipeline deal in Sudan.(IHT 27/28-12-97)

\section{Division and sharing of Caspian oil}

An agreement was concluded by Russia and Kazakhstan on the division of the northern part of the Caspian Sea into sectors and their allocation to each of the two states. Yet Kazakhstan agreed to a sharing of the Caspian waters, allowing both states equal access to the sea's fishing grounds. The accord was seen as a victory for Kazakhstan, given that it recognized the latter's claim to the oil near its coast.

The five states on the Caspian Sea had been divided over the question of ownership of the oil in the seabed. The three states with oil near their coastlines - Kazakhstan, Azerbaijan, and Turkmenistan - wanted the Caspian divided into national sectors while Russia and Iran, with little or no oil near their Caspian coasts, wanted the maritime resources to be shared by all.(IHT 07-07-98)

Iran reacted by stating that it would not recognize the agreement. It said that the five countries bordering the Caspian Sea "should reach a comprehensive agreement on a just and equitable share-out of the Caspian resources".(IHT 09-07-98)

\section{Turkmenistan-Afghanistan-Pakistan pipeline project}

Unocal Corp. withdrew from the Central Asia Gas Consortium (see 7 AsYIL 469) in early December 1998. The consortium project included a 1,600-kilometre oil pipeline and a companion 570-kilometre natural-gas pipeline.(IHT 07-12-98) 


\section{ORGANIZATION OF THE ISLAMIC CONFERENCE (OIC)}

\section{Summit Conference}

In early December 1997 Iran hosted the (tri-annual) eighth summit meeting of the organization, which has fifty-five member-states.(IHT 08/09-12-97).

\section{RECOGNITION}

See: Association of South East Asian Nations: Admission of Cambodia

\section{REFUGEES}

\section{Myanmar Muslims deported from Bangladesh}

(See also: 2 AsYIL 347; 3 AsYIL 424; 4 AsYIL 502; 5 AsYIL 482)

Bangladesh on 20 July 1997 resumed its repatriation of 21,000 Myanmar Muslims from Bangladesh frontier camps, among about 250,000 Muslims, known as Rohingyas, who had fled to Bangladesh in 1992 in escaping alleged repression and human rights violations. Most were sent back after a 1993 accord.(IHT 21-07-97) In late July 1997, however, the UNHCR won a commitment from Bangladesh to halt the forcible repatriation.(IHT 28-07-97)

\section{Myanmar-Thailand}

Thailand and Myanmar agreed 9 December 1997 to establish a panel to screen about 100,000 refugees along their common border to determine whether they were fleeing persecution or merely for economic reasons.(IHT 10-12-97)

\section{Deportation of Indonesian illegal immigrants from Malaysia}

(See also: Migrant workers)

Among illegal immigrants who were to be deported from Malaysia were persons from the Indonesian province of Aceh who feared persecution in Indonesia. The Indonesian foreign minister denied this and said they should be deported by Malaysia as illegal immigrants without a right to claim refugee status. He also referred to an Indonesian-Malaysian agreement on illegal immigrants.(IHT 13/14-04-98)

\section{Bhutanese refugees in Nepal}

Relations between the two countries had been strained as a result of a great number of Nepali Bhutanese living in refugee camps in Nepal (see 2 AsYIL 349; 3 AsYIL 423; 7 AsYIL 461). Talks to resolve the issue were to be resumed in January 1999.(IHT 27-11-98) 


\section{REGIONAL SECURITY}

See also: Inter-state relations: China - US

\section{US claim to flexibility of movement for its forces}

The US Defense Secretary stated, at a forum of political and defence experts at Kuala Lumpur on 12 January 1998, that the US military would not accept any restrictions on its freedom of movement in the Asia-Pacific region, even from wellintentioned friends and allies. He also said that the US was concerned about informal proposals for confidence building measures from ASEAN officials, which could require advance notice of the size and timing of US force movements.(IHT 13-01-98)

\section{Northeast Asian regional security body}

During his official visit to China in November 1998 the South Korean president called for the creation of a Northeast Asian regional security body to manage territorial disputes and military tension.(IHT 13-11-98)

\section{RIVERS}

\section{Indo-Bangladesh co-operation}

India and Bangladesh agreed on 20 July 1997 to take immediate steps to resolve a water-sharing problem over the Teesta (Tista) River and to continue co-operation in flood management, ending a major disagreement between the two countries.

Water sharing from the Teesta (Tista) and 53 other rivers that run in both countries came up for discussion in the Indo-Bangladesh Joint Rivers Commission, meeting after a break of seven years.(IHT 21-07-97)

\section{SANCTIONS}

See also: International economic relations and trade

US legislation on sanctions in connection with Indian and Pakistani nuclear weapon tests

(See also: Nuclear energy matters, supra at 298)

Frequent US sanctions against policies of Asian countries highlight the relevance of US legislation in the field.

Under the US Arms Export Control Act nuclear weapon tests by a non-declared nuclear weapons state, if confirmed by the president, oblige him to suspend foreign aid and military assistance, bar sales of military and other non-humanitarian exports, vote against the country in international financial institutions and prohibit US banks from making loans to the state concerned, except for agricultural purchases. The president can waive the sanctions if he determines them to be against US national security but the Congress has the power to override the waiver.(IHT 12-05-98) 


\section{US economic sanctions relating to Iran}

The US Iran-Libya Sanctions Act (see 7 AsYIL 474) prohibited non-US investment of more than $\$ 20$ million in Iran and prescribed punitive trade measures in case of violation. [All commerce between US companies and Iran had been banned earlier by executive order]. However, sanctions might be delayed or waived in the national interest if the country involved was shown to deter Iran from sponsoring terrorism. This had not prevented the conclusion of a multi-billion contract between the French oil company Total and the National Iranian Oil Company, giving rise to US protests and threats and French warning of the US not to retaliate. The agreement, in which the Russian Gazprom and the Malaysian Petronas also held a stake, was aimed at producing natural gas from South Pars field.(IHT 30-09 and 01-10-97) Shortly after the Total-NIOC contract, another French oil company, Elf, confirmed that it was also pursuing oil exploration and production deals with, inter alia, Iran.(IHT 02-10-97) Yet another agreement on offshore oil development was signed by (Canadian) Bow Valley Energy Ltd. and its Indonesian partner, Bakrie Minarak.

Reacting to the European protests against measures under the act and threats of a formal complaint with the WTO, the US considered holding off sanctions in exchange for increased European pressure on Iran to curb "terrorism" and, generally, to isolate Iran.(IHT 06-10 and 12-11-97)[Another factor that played a role in the US evaluation of one of the investment cases was the fact that Gazprom was not only participating in the investment but was also preparing a $\$ 1$ billion bond-issue on financial markets including the US markets, and stopping the issue would mean interfering with efforts to stabilize the Russian economy. Besides, the main underwriter of the Russian bond issue was GOLDMAN SACHS, one of biggest financial supporters of the CLINTON campaign, with RUBIN, at that time Finance Secretary, being its former co-chairman.(IHT 17-10-97) Moreover, under an agreement between Gazprom and the US Exim Bank the latter guaranteed $\$ 750$ million in financing Gazprom purchases of US equipment. In December 1997 Gazprom cancelled the agreement.(IHT 19-12-97)]

All these and other intricacies and complexities involved led the US to refrain from any action.(IHT 23-03-98)

In late April 1998 it was reported that a consortium led by Royal Dutch/Shell Group and including Petronas (Malaysia) and Gaz de France intended to enter a framework agreement for the development of Iranian offshore gas reserves of parts of the South Pars field for export to Pakistan. The project would involve the construction of a 1,600-kilometre pipeline linking Iran with Karachi and Multan in Pakistan.(IHT 28-04-98)[On 18 May 1998 the US and the EU reached a solution for their dispute: the US would seek Congressional waiver of the sanctions, and the European states committed themselves to stepping up cooperation in combating terrorism and fighting the spread of weapons of mass destruction; this included EU support in persuading Russia to cease assisting Iran in its ballistic missile program.(IHT 19-05-98)] 


\section{Enforcement of UN sanctions against Iraq}

Iran in mid-February 1998 began effectively taking steps to close loopholes in the economic embargo of Iraq (see UNSC res.687) by acting against those oil shipments that broke sanctions. The amounts concerned were, however, too small to make a significant difference to the market price of oil. It was interpreted by the US as a gesture to show goodwill to the US. Most of these oil transports by barges and small boats were using forged Iranian manifests and passed through Iranian waters into UAE ports.(IHT 17-03 and 27-03-98)

\section{US sanctions against Pakistan}

(See also: Missile technology: Pakistan)

There were new developments in the case of the jet fighter planes ordered by Pakistan but never delivered as a consequence of the so-called Pressler Amendment (see supra at 293; and 1 AsYIL 271; 2 AsYIL 286; 4 AsYIL 508; 5 AsYIL 486; 6 AsYIL 338;449). New Zealand agreed to acquire the 28 F-16 fighters on a ten-year lease-buy arrangement. However, there was still no clarity about the amount to be reimbursed to Pakistan.(IHT 03-12-98)

\section{Western sanctions against China}

After having started selling weapons to China since the 1980s as part of its strategy to weaken the Soviet Union by strengthening China, the Tiananmen incident caused the US to introduce a string of sanctions, among which was a ban on weapons sales. There was also a prohibition against Chinese launches of US satellites, relaxed on a case-by-case basis because of an enormous backlog in satellite launches around the world. For instance, such a launch did take place on 12 June 1999.

The European Community (Union) also instituted a weapons embargo, which was based on a gentlemen's agreement among member states and was not legally binding.(IHT 25-05-98 and 14-06-99)

\section{SELF-DEFENCE}

See also: (Non-)Intervention; Missile technology: North Korea; Territorial sovereignty; Weapons

\section{Japanese spy satellites}

The government announced on 6 November 1998 that Japan would launch a series of intelligence-gathering satellites within five years, beginning in the spring of 2003. The long-held plans were reaching realization because of alarm at the launch of a North Korean rocket in September 1998. (See: Missile technology, supra at 292)(IHT 07/08-11-98)

\section{Pre-emptive strikes as self-defence}

In connection with the North Korean launch of a three-stage rocket (see supra at 292) it was stated on behalf of the Japanese prime minister that Japan has the 
theoretical right to carry out pre-emptive strikes against countries that pose a military threat. The official was quoted as saying: "I think it was already clarified many years ago in Parliament that, theoretically, self-defence could include pre-emptive attacks on the territory of a country which is contemplating a military attack on Japan."

In response to the statement a Chinese foreign ministry spokesman said that Japan's attitude "would only lead to confrontations and tensions in the region and be quite disturbing for Japan's neighbours."(IHT 10-03-99)

\section{SELF-DETERMINATION}

\section{East Timor}

(See also: previous Volumes of this Yearbook under: Specific territories within a state: East Timor)

[Indonesia had invaded the former Portuguese colony and annexed it in 1976. The UN had not recognized this annexation and continued to regard Portugal as the administering power of East Timor.]

For the first time in twenty years the Indonesian government signalled its willingness to address the status of East Timor. On 9 June 1998 the president of Indonesia proposed that the territory be granted a special administrative status while ruling out the possibility of independence. He later emphasized that the proposal was contingent on an agreement by the UN and Portugal to recognize Indonesian control of the territory. The separatists immediately rejected the proposal.(IHT 11-06-98)

Later one of the independence leaders said he would accept an offer of limited autonomy within Indonesia now and a five-year delay on a referendum on the territory's permanent status. But he would not agree to the recognition of Indonesian sovereignty in the meantime.(IHT 01-07-98) On 5 August 1998 Portugal and Indonesia reached agreement on the outlines of an autonomy plan that would give East Timor the right to self-government except in foreign affairs and defence; however, the East Timorese leaders were not prepared to join any talks while their main resistance leader was detained in prison in Indonesia.(IHT 06/07-08-98)

On 27 January 1999 the Indonesian foreign minister, with the president's sanction, said that if the Indonesian offer of autonomy (see above) were rejected, the government would propose that Indonesia's highest legislative body, the People's Consultative Assembly, should consider granting independence to East Timor after the national elections of 7 June 1999. In response to calls by the UN Secretary General Indonesia also moved the imprisoned East Timorese resistance leader from prison to de facto house arrest.(IHT 28-01 and 11-02-99)

Meanwhile Indonesia continued talks with Portugal to try to reach an agreement on the territory. It was difficult to reach agreement on the question of how to gauge whether a majority of the population supported autonomy and whether such autonomy should be a stepping stone to an act of self-determination such as a vote on independence in a referendum supervised by the UN. Indonesia was against a referendum as it could cause civil conflict.(IHT 04-02-99) 
On 11 February 1999 the Indonesian president vowed that a solution of the Timor crisis be achieved by the end of the year, and that if the autonomy package was rejected, then East Timor could become independent.

In an effort to bridge the remaining differences the Indonesian foreign minister stated on 11 March that Indonesia would back a "direct vote" by the people of East Timor on the Indonesian draft autonomy package, but he again rejected a UN proposal, backed by Portugal, for election of a consultative assembly that would decide on the autonomy question.(IHT 12-03-99) The Indonesian proposal was finally accepted, and it was agreed that a direct vote on the autonomy plan would be organized under UN auspices but without the official requirements of a referendum. Indonesia said that it would grant independence if the autonomy plan was rejected.(IHT 13/14-03-99)

Unfortunately, the East Timorese leader, from his house arrest, called for an armed uprising against pro-Indonesian forces in early April 1999, although previously he had steadfastly urged his supporters to maintain a cease-fire and work for peace and reconciliation. The immediate cause of his reversal of policy appeared to be reports about attacks by pro-Indonesian militia on pro-independence groupings, particularly an attack on a church at Liquica on 6 April 1999 involving the killing of tens of civilians. He blamed the international community for its failure to intervene to halt the conflict.(IHT 07-04-99) However, Indonesia kept refusing to allow a UN civilian presence to be established on the ground until agreement was reached with Portugal on details of the proposed ballot. On the other hand the UN (and Australia) made it clear that a UN peacekeeping force cannot be sent to the territory unless it was invited by Indonesia and had a peace to keep.(IHT 14-04-99)

As referred earlier, a long-time unsolved question in the Indonesia-Portugal talks was how to gauge whether a majority of the East Timorese population support autonomy and whether it should be followed by an act of self-determination for independence in a referendum supervised by the UN.(IHT 20-04-99)

A UN-brokered agreement was finally reached on 23 April 1999 and signed on 5 May 1999.(IHT 24/25-04-99) The UN-sponsored vote was to be held on 8 August, which date was later postponed two weeks due to the security situation in the territory. It would be supervised by at least $600 \mathrm{UN}$ monitors and police advisers. Under the agreement Indonesia was committed to disarm rival political groups and ensure the neutrality of the Indonesian armed forces, which would have the primary responsibility for providing security in the run-up to the vote.(IHT 29-04 and 07-05-99)

Pro-independence and pro-autonomy factions in June 1999 signed a principle accord on disarming and withdrawals while follow-up talks took place at Jakarta in late June on implementation. They were organized, with Indonesian blessing, by Church authorities.(IHT 26/27-06 and 28-06-99)

A first attack against the UN presence took place when pro-Indonesian militiamen surrounded a new outpost of the UN Assistance Mission in East Timor (UNAMET) on 29 June 1999 and showered the building with stones. According to the Indonesian foreign ministry, however, the incident was merely a brawl between rival factions throwing stones at each other.(IHT 30-06-99) 


\section{SPACE ACTIVITIES}

See also: Sanctions

\section{US satellites for China}

The US contemplated to revise a decision taken in June 1996 (announced in February 1996, see 6 AsYIL 453) to allow the sale of certain satellites to China. The satellites would be the cornerstone of a commercial mobile telephone network for China and twenty-one other Asian countries. They would include an antenna of a type that is common in US and Russian eavesdropping satellites, and of a nature that was inherently dual-use.(IHT 19-06-98)

SPECIFIC TERRITORIES WITHIN A STATE: EAST TIMOR

See: Self-determination

\section{SPECIFIC TERRITORIES WITHIN A STATE: KASHMIR}

\section{Indian air strikes and Pakistani response}

Pakistani armed forces on 27 May 1999 shot down two Indian fighter planes that they said had crossed six to eight kilometres inside the Pakistan-controlled portion of Kashmir. It happened during a fourth round of Indian air strikes aimed at dislodging pockets of Muslim guerrilla infiltrators inside India-controlled Kashmir (see infra). Indian officials insisted that their jetfighters had not crossed into Pakistani airspace intentionally and that only one plane had been hit by hostile fire. They said that one plane had developed engine trouble on the Indian side of the cease-fire line and might have flown into Pakistan-controlled territory as the pilot ejected from the cockpit and that the second had followed it to assist and was shot down on the Indian side of the line. The officials emphasized that there were no aggressive intentions against Pakistan.(IHT 28-05 and 29/30-05-99)

\section{Renewed fights near Kargil}

In May 1999 about 700 Islamic guerrillas, or, according to Indian description, infiltrators supported by Pakistan and including members of the Pakistani Army, had seized mountaintop positions a few miles inside Indian territory in the Kargil area, overlooking supply routes extending from the Kashmir Valley to an important Indian military base in Ladakh. Indian forces normally held these positions in warmer months and abandoned them during the winter. When Indian troops wanted to re-occupy them in May, the ridges had by then been seized by hostile forces. This gave rise to renewed fighting, the most intense in 30 years, including the use of fighter planes (see supra) as India tried to recapture the territory. Since it was estimated to have taken a few months to plan and execute the encroachment with the precision and back-up support shown, the suspicion was that it was plotted in Pakistan at the time of the Lahore meeting of the prime ministers in February 1999. 
The foreign ministers of the two countries met on 12 June 1999 to try to defuse the tensions but the talks did not result in easing the disagreements. The Indian prime minister then said that India was willing to hold further talks only if Pakistan stopped violating the Line of Control in Kashmir. The US and other states, among which China and Russia, strongly called for a de-escalation of tensions, and urged the guerrillas and eventual supporting Pakistan forces to withdraw their forces. The turnaround in US policy was noteworthy. After its previous campaign against India after the latter's nuclear tests and its understanding for the Pakistani response, India was now drawing praise for its restraint in the Kashmir conflict while Pakistan was being criticized. The US appeared convinced that the bulk of the intruders were regulars from the 10th Corps of the Pakistani Army.

Meanwhile in late June 1999 Indian forces had re-conquered much of the territory and for the first time Indian authorities said that they would consider sending troops into Pakistani territory if necessary, i.e., if Pakistan did not pull back from the seized territory.(IHT 28-05; 29/30-05;04-06;09-06;14/15-06; 26/27-06 and 28-06-99)

\section{STATE RESPONSIBILITY}

See: Diplomatic and consular relations: Iran-Argentina; Inter-state relations: IranPakistan; Jurisdiction

\section{TERRITORIAL CLAIMS AND DISPUTES}

\section{Spratly Islands}

Philippine military officials divulged that the Philippines had torn down new structures allegedly built by the Chinese near the disputed Spratly Islands, on a rocky outcrop called Sabina Shoal, 120 kilometres west of Palawan Island.(IHT 01-07-97) It was reported that China had protested the removal, but the Philippine foreign minister emphasized the Philippines would continue the removal of Chinese markers on Philippine-claimed territory.(IHT5/6-07-97)

The Philippine navy arrested twenty Chinese fishermen in late November 1998 for having fished near Alicia Annie Reef, which is claimed by both countries (in August twenty-three Chinese fishermen were arrested in similar circumstances but were later released after charges against them were dropped). China demanded their release, describing the arrest as "illegal". The Philippine side responded that the fishermen would be released "after an appropriate time" and with a lecture about not poaching in waters claimed by the Philippines.

It was reported that the Philippine and Chinese presidents had discussed the dispute over the islands and had agreed to settle it peacefully and to have the natural resources used jointly by the two countries.(IHT 01-12, 02-12-98)

It was reported in January 1999 that the Philippines planned to call a meeting among countries with rival claims to the islands and the US in an effort to reduce tensions but this attempt to involve other claimants in resolving the Philippine Chinese dispute over Mischief Reef seemed to have failed. Malaysia and Vietnam 
said that the dispute should be settled by the claimants concerned themselves, the US said that it had not taken a position on the sovereignty of the islands, and China rejected the proposal because it included the US.

According to Philippines sources in February 1999 the permanent structures being built by China (see this Yearbook, Vol.5 at 495) were completed that month.(IHT 13-01;21-01 and 17-02-99)

The two countries again held talks in March 1999.(IHT 23-03-99)

\section{Kurils (Northern Territories)}

It was reported that the Russian foreign minister told his Japanese colleague that Russia would offer plans for jointly developing the disputed islands, but that the Japanese minister said Japan could not accept such plans as they assume Russian sovereignty as a precondition. Proposals to this effect were floated on the occasion of a summit meeting in early November 1997 (see supra, Inter-state relations: JapanRussia; Joint development and joint ventures).

The two sides agreed to take steps to prevent recurrence of incidents as took place late June 1997 in which Russian vessels fired warning shots at Japanese fishing boats in Russian waters near the disputed islands.(IHT 01-07 and 03-11-97)

At the next summit meeting in April 1998 the dispute was not solved, but a proposal on the issue was submitted by the Japanese side and would be studied by the Russians.(IHT 18/19-04 and 20-04-98). In January 1999 there were unconfirmed reports according to which the Japanese government intended to propose an interim treaty that would involve the return to Japan of two of the four islands, Shikotan and Habomai.(IHT 07-01-99)

\section{Myanmar-Thai dispute over Manao Island}

The two countries claim rights over the small island, located in the Moei River that separates the Thai town of Mae Sot from the Myanmarese city of Myawaddy. Both countries have troops stationed on the island and in early February 1998 there were reports of the Myanmarese having fired on a Thai military plane that flew near the disputed island.(IHT 03-02-98)

\section{Scarborough Shoal/Huangyan Island}

This shoal is located outside the Spratly Islands and is claimed by the Philippines and China. On 23 May 1999 a Philippine navy patrol ship and a Chinese fishing boat collided near the shoal resulting in the sinking of the Chinese boat. According to the Philippine foreign ministry the patrol ship was conducting "routine sovereignty and maritime patrol" and caught up with the fishing vessel about seven kilometres northwest of Scarborough when strong waves caused the vessel accidentally to hit the Philippine ship and sink. China contended that the navy ship had rammed the wooden junk.

China rejected the Philippine claim that the island lies within the 200-mile exclusive economic zone of the Philippines. Chinese ancient historical documents as well as Chinese maps from 1935 to 1983 support the Chinese claim, while neither 
Philippine treaties dating from 1898 nor the 1935 constitution show a similar claim on the Philippine behalf.(IHT 25-05;27-05 and 11-06-99)

\section{TERRITORIAL SOVEREIGNTY}

See also: Inter-state relations: China-US

\section{Iranian attacks on Mujahidin Khalq in Iraq}

Iranian planes on 29 September 1997 bombed two military bases of the Iranian opposition group Mujahidin Khalq inside Iraq, near the city of Kut. The Iraqi foreign ministry accused Iran of having violated "Iraq's sovereignty and airspace".(IHT 30-0997) The intrusion met with sharp US condemnation, arguing that the attacks "complicate the enforcement of the no-fly zone". [This refers to both northern and southern no-fly zones designated and enforced unilaterally by the US and the UK without UN authorization.](IHT 04/05-10-97)

Iraq accused Iran on 11 June 1999 of firing three long-range missiles into a military base of the Mujahidin Khalq on Iraqi territory. Iran appeared to have stepped up attacks on the Mujahidin since the group claimed two months before that it had assassinated the Iranian armed forces deputy chief of staff.(IHT 12/13-06-99)

\section{Foreign vessels in Japanese waters}

Japanese patrol boats and aircraft spotted and chased two vessels of unknown origin in Japanese waters and fired warning shots in order to stop the vessels to be boarded. It invoked the right to self-defence under which its Self-Defence Forces are authorized to try to board the vessels, which fled north into international waters. The Maritime Safety Agency said that it had spotted one of the ships on 23 March 1999 about 45 kilometres east of the Noto Peninsula in central Japan on the side facing the Korean Peninsula.

The Japanese response was startling since it often occurred that foreign vessels fish or drop off smuggled cargoes or illegal aliens without generating such serious response. IHT 24-03-99)

It became clear later that the vessels were suspected to be from North Korea, and the following day Japan urged that North Korea seize and hand over the vessels.(IHT 25-03-99) However, North Korea through its representative at the UN informed Japan that it had nothing to do with the ships.(IHT 27/28-03-99)

\section{TERRORISM}

See also: Inter-state relations: Iran-US; (Non-)Intervention; Jurisdiction; Sanctions

\section{Liberation Tigers of Tamil Eelam classified as terrorists}

The Liberation Tigers of Tamil Eelam (LTTE), the Tamil insurgent movement in Sri Lanka, was listed by the US as a terrorist organization in October 1997.(IHT 17-10-97) [The US classification bars the organization from raising money in the US and the members from entering the US.] 
Sri Lanka urged the international community to follow the US measure, as such action would strengthen the battle against the rebels. (JP 10-10-97)

\section{UNITED NATIONS}

\section{Chinese budget contribution}

The US had asked China to consider paying 4 percent of the UN regular budget to help cover the gap that would arise if it succeeded in having its assessment reduced to 20 percent from the current 25 percent. China currently paid 0.7 percent. (IHT 01-09-97)[See 5 AsYIL 502-3 for the status of Asian contributions to the UN regular budget]

\section{Asian attitudes in UN Security Council}

Japan co-sponsored a British initiated draft resolution authorizing automatic use of force if Iraq violated an agreement under which it would allow UN arms inspectors entry into presidential palaces. On the other hand China joined Russia and France in heading off such authorization. They wanted to ensure that the full Council would determine whether Iraq had violated the agreement and, if so, what response would be appropriate. The Council meeting ended with no agreement on the final language of the resolution. (IHT 28-02/01-03-98)

Finally, the resulting resolution 1154, adopted 2 March 1998, read, in its paragraph 3: "Stresses that compliance by the Government of Iraq ... is necessary for the implementation of resolution 687(1991) [i.e. the main resolution establishing the cease fire and the sanctions ending the Gulf War], but that any violation would have severest consequences for Iraq". (IHT 03-03-98)

When the US interpreted the resolution as allowing the UN member states to take unilateral action in case of violation, that interpretation was disputed by, inter alia, China, which interpreted the resolution to mean that military action cannot be taken against Iraq without specific authorization by the Council. (IHT 04-03-98)

\section{UN intervention in Myanmar political dissension}

It was reported that the UN and the World Bank were offering $\$ 1$ billion in financial and humanitarian aid in exchange for opening a dialogue with the opposition. It was the first UN attempt to include international financial institutions directly in political negotiations. It was said that the bulk of the funds would come from Japan. If the plan would proceed, the US would withdraw its long-standing automatic veto of any funding or assistance for Myanmar from the IMF and the World Bank.(IHT 26-11-98)

\section{Chinese veto}

China announced its intention to veto an extension of a UN peacekeeping force in the Republic of Macedonia. It said that it had opposed such extension before because it did not consider the situation in Macedonia to represent a threat to inter- 
national peace. There were suspicions that the real reason lay in the fact that Macedonia had established diplomatic ties with Taiwan.

China had only used its veto power four times before, most recently in 1997 when it voted against sending a UN mission to Guatemala. Guatemala had invited a Taiwanese delegation to attend a ceremony marking a treaty that ended the civil war.(IHT 25-02-99)

\section{UN-sponsored settlement of Kosovo conflict}

With regard to the efforts to terminate the conflict in Kosovo, China, as a permanent member of the UN Security Council, said on 11 May 1999 that NATO must stop its bombing of Yugoslavia before it would consider an international peace proposal, but the US rejected the suggestion.(IHT 12-05-99)

The Chinese attitude was maintained in respect of the Kosovo peace plan supported by the West and Russia in May 1999: a halt to the NATO bombing campaign as a "precondition" of Security Council talks. China had vehemently opposed the campaign, arguing that it sets a dangerous international precedent of "human rights over sovereignty".(IHT 09-06-99)

Finally, NATO did suspend its bombing, and the UN Security Council voted 14-0, with China abstaining, for a resolution authorizing an international peacekeeping force.(IHT 11-06-99)

\section{WEAPONS}

See also: Nuclear energy matters

\section{India declares possession of chemical weapons}

Among the states which were party to the 1993 Convention on the Prohibition of the Development, Production, Stockpiling and Use of Chemical Weapons and on Their Destruction two states (US and Russia) had declared to be in possession of chemical weapons stockpiles, and another half dozen had declared to have the ability to make them. Under the treaty these declarations may be made under condition of secrecy.

Several months after the entry into force of the Convention (29 April 1997) India openly declared its possession of a chemical weapons stockpile.(IHT 18-08-97)

\section{Chinese attitude toward land mines}

China on 30 November 1997 stated its objection to plans for a treaty to ban land mines because it needed land mines for self-defence. It supported reasonable restrictions over the use of such mines but reserved the right to use them on its own soil, to defend its borders. The general principle in solving the problem should be one that takes balanced account of both humanitarian concerns and the legitimate needs of sovereign states for self-defence.

In September 1997 nearly hundred states had reached agreement on banning the use, stockpiling and production of anti-personnel land mines. The treaty was signed at a conference in Ottawa on 5 December 1997. (IHT 01/02-12 and 03-12-97) 


\section{Chinese prevention of chemical weapon proliferation}

China on 17 December 1997 issued new rules to tighten controls on the import and export of chemical weapon-related materials.(IHT 18-12-97)

\section{China-US on use of nuclear weapons}

According to newspaper reports, China and the US were negotiating an agreement to retarget their nuclear missiles away from each other. China maintained that such agreement should be preceded by another agreement pledging no first use of nuclear weapons. The US refused to make such a pledge as being meaningless and unverifiable. [China had 18 long-range missiles; the US had about 6,000 nuclear warheads.](IHT 19-06-98) The mutual pledge was after all made as one of the results of the visit of the US president to China in late June 1998.(IHT 06-07-98)

\section{Indian response to Sino-US joint communiqué}

The Sino-US communiqué issued on the occasion of the visit of the US president to China in late June 1998 called, inter alia, on India and Pakistan to curb their nuclear and missile programmes.

India accused the two countries of hypocrisy and showing a "hegemonistic mentality". The statement said, inter alia, "It is most ironical that two countries that have directly and indirectly contributed to the unabated proliferation of nuclear weapons and delivery systems in our neighbourhood are now presuming to prescribe the norms for non-proliferation."(IHT 29-06-98)

\section{Indian and Pakistan attitudes toward the Comprehensive nuclear test ban treaty}

After they had conducted their nuclear tests in May 1998 both India and Pakistan declared they would be prepared to participate in the treaty if some conditions would be fulfilled. Thus, Pakistan demanded the US to lift its sanctions and help Pakistan with an aid package to prevent its default on $\$ 30$ billion in debt. India wanted, inter alia, the lifting of sanctions and the possibility to buy advanced technology from the US.(IHT 01-10-98)

\section{WORLD WAR II}

\section{Damages for comfort women}

(See also: 2 AsYIL 383; 3 AsYIL 453; 4 AsYIL 525; 5 AsYIL 506; 6 AsYIL 467; 7 AsYIL 491)

The (Japanese) District Court of Yamaguchi sentenced the Japanese state to pay damages to three Korean women for having forced them into sexual slavery for Japanese soldiers during World War II. The court called it a "fundamental violation of human rights", and found that the government should have passed laws to repay the women for their suffering. The ruling was the first in a lawsuit filed by so-called "comfort women". 
The court rejected the claims of seven other plaintiffs, who had been forced to work in Japanese military plants, but were not sex slaves.(IHT 28-04-98)

\section{No compensation for former prisoners-of-war}

A Tokyo court rejected a claim for compensation filed by former soldiers and civilians of states with which Japan had been at war and who had been held prisoner by Japanese troops during World War II.

The lawsuit was filed by seven plaintiffs, on behalf of 20,000 nationals of Australia, Britain, New Zealand, and the US, in 1995. It was the first decision in such a case. The court ruled that the issue was resolved on the government level in 1951 with the signing of the peace treaty.(IHT 27-11-98) 